University of Chicago Law School

Chicago Unbound

Journal Articles

Faculty Scholarship

1962

\title{
Legislative Apportionment and Representative Government: The Meaning of Baker v. Carr
}

Jo Desha Lucas

Follow this and additional works at: https://chicagounbound.uchicago.edu/journal_articles

Part of the Law Commons

\section{Recommended Citation}

Jo Desha Lucas, "Legislative Apportionment and Representative Government: The Meaning of Baker v. Carr," 61 Michigan Law Review 711 (1962).

This Article is brought to you for free and open access by the Faculty Scholarship at Chicago Unbound. It has been accepted for inclusion in Journal Articles by an authorized administrator of Chicago Unbound. For more information, please contact unbound@law.uchicago.edu. 


\section{LEGISLATIVE APPORTIONMENT AND REPRESENTATIVE GOVERNMENT: THE MEANING OF BAKER $V$. CARR}

\section{Jo Desha Lucas*}

$I^{N}$ $\mathrm{N}$ three recent cases the Supreme Court has reopened the question of the extent to which federal courts will review the general fairness of state schemes of legislative apportionment. It is a question on which the Court has had nothing to say for over a decade, leaving the bar to patch together the current state of the law from the outcome of cases disposed of without opinion considered against a backdrop of language used in earlier decisions.

\section{Baker v. Carr}

In Baker v. Carr $^{1}$ there was full atonement for past laconism. There were six opinions, totalling some 50,000 words, and the case was returned to the district court with an order to hear it on the merits, suggesting that there are more to come. A simple theme has not undergone such exhaustive exploration since the publication of Beethoven's "Thirty-three Variations on a Waltz by Diabelli."

Baker was a suit brought in a three-judge district court seeking a declaration that the retention in 1961 of the scheme provided by the Tennessee Legislative Apportionment Act of 1901, ${ }^{2}$ contrary to provisions of the state constitution, ${ }^{3}$ violated the Constitution of the United States in that it resulted in under-representation of districts of greatly increased population, thus depriving the residents of such districts of equal protection of the laws. ${ }^{4}$ The defendants, election officials of the state of Tennessee, moved to dismiss on three grounds: first, want of jurisdiction over the subject matter; second, failure to state a claim upon which relief can be granted; and third, absence of indispensable parties. ${ }^{5}$ The district court granted the motion and dismissed the bill. In a per curiam opinion, it conceded that the state constitution and the "rights" of the plaintiffs had been violated by the failure of the

* Professor of Law, University of Chicago.-Ed.

1369 U.S. 186 (1962).

2 Acts of the State of Tennessee ch. 122 (1901).

3 Tenn. Const. art. II, §§ 3-6.

4 U.S. ConsT. amend. XIV, \& 1.

5 Baker v. Carr, 369 U.S. 186 (1962). 
Tennessee legislature to reapportion, but, after reviewing the Supreme Court decisions from Colegrove v. Green ${ }^{6}$ to Matthews v. Handley, ${ }^{7}$ read those cases as precluding intervention on the part of federal courts, and went on to suggest that the case at bar illustrated the wisdom of the rule of non-intervention. ${ }^{8}$ Quoting from Mr. Justice Frankfurter's opinion in Colegrove v. Green, the court gave other examples of political controversies into which the federal courts had refused to intrude. ${ }^{9}$ On appeal, the Supreme Court held that the question was within the subject-matter jurisdiction of the courts and was not a non-justiciable "political question," reversing the district court and remanding the case for a decision on the merits of the constitutional claim. ${ }^{10}$

Similar attempts to invalidate state statutes apportioning political influence among the state's geographically-defined political subdivisions had been before the Supreme Court fifteen times in the past thirty years, all unsuccessfully. ${ }^{11}$ To show that the district court should try Baker $v$. Carr ${ }^{12}$ on the merits it was necessary to dispose of these decisions.

6328 U.S. 549 (1946).

7361 U.S. 127 (1959).

8 The Court referred to earlier litigation of the same issues by the Supreme Court of Tennessee. See Kidd v. McCanless, 200 Tenn. 273, 292 S.W.2d 40, appeal dismissed, 352 U.S. 920 (1956). See discussion of Kidd v. McCanless in the text infra at 736-37.

9 Baker v. Carr, 179 F. Supp. 824, 828 (M.D. Tenn. 1959). See Colegrove v. Green, 328 U.S. at 556.

10 Baker v. Carr, 369 U.S. 186 (1962).

11 Matthews v. Handley, 361 U.S. 127 (1959); Hartsfield v. Sloan, 357 U.S. 916 (1958); Radford v. Gary, 352 U.S. 991 (1957); Kidd v. McCanless, 352 U.S. 920 (1956); Anderson v. Jordan, 343 U.S. 912 (1952); Cox v. Peters, 342 U.S. 936 (1952); Remmey v. Smith, 342 U.S. 916 (1952); Tedesco v. Board of Supervisors, 339 U.S. 940 (1950); South v. Peters, 339 U.S. 276 (1950); MacDougall v. Green, 335 U.S. 281 (1948); Colegrove v. Barrett, 330 U.S. 804 (1946); Cook v. Fortson (Turman v. Duckworth), 329 U.S. 675 (1946); Colegrove v. Green, 328 U.S. 549 (1946); Wood v. Broom, 287 U.S. 1 (1932). It has sometimes been suggested that there may be a constitutionally significant distinction between cases dealing with congressional apportionment and those which treat of representation in the state legislatures. See, e.g., Dixon, Legislative Apportionment and the Federal Constitution, 27 LAW \& Contemp. PROB. 329, 339-40, 344 (1962). There is language in the Frankfurter opinion in Colegrove $v$. Green which lends support to this view, for there it is said, at 554: "The short of it is that ... the subject has been committed to the exclusive control of Congress." It should be noted, however, that this language was rejected by Mr. Justice Rutledge, whose vote was necessary to the disposition of the case, that it has never been repeated by the Court, and that Colegrove v. Green was coupled with Colegrove $v$. Barrett (dealing with state representation) in disposing of MacDougall $v$. Green (dealing with presidential electors). Indeed, the distinction may be looked upon as an effort to distinguish Colegrove v. Green; it is highly unlikely that it will be advocated with much fervor in preserving the Colegrove doctrine in congressional apportionment. See, e.g., Black, Inequities in Districting for Congress: Baker v. Carr and Colegrove v. Green, 72 YALE L.J. 13 (1962).

12369 U.S. 186 (1962). 


\section{A. The Majority Opinion: Disposing of Colegrove and Its Progeny}

Mr. Justice Brennan, in writing the Court's majority opinion in which the Chief Justice and Mr. Justice Black joined, first characterized the opinion of the district court as conceding the violation of rights guaranteed the plaintiffs by the Constitution of the United States ${ }^{13}$ and proceeding upon the assumption either that the subject matter was not within the jurisdiction of the court, or that, although within the subject-matter jurisdiction, the issues were nevertheless political matters by their nature non-justiciable. After considering each of these grounds in turn, he concluded that both assumptions were unsupported by prior Supreme Court decisions. ${ }^{14}$

The question of jurisdiction over the subject matter of the controversy is hardly worth the discussion it has received. True, there is language in the Frankfurter opinion in the Colegrove decision $^{15}$ to the effect that the direct grant to the states to control the time, manner, and place of holding elections for congressmen, coupled with a power of revision vested in Congress and a power in Congress to serve as sole judge of the election of its members, ${ }^{16}$ indicates an intention to take questions of congressional apportionment out of the jurisdiction of courts of law. It is doubtful if this language can be taken as suggesting that apportionment problems are outside the subject-matter jurisdiction of the federal courts in the sense that they are not within the constitutional definition of the judicial power. As Mr. Justice Clark pointed out in Baker $v$. Carr, ${ }^{17} \mathrm{Mr}$. Justice Frankfurter and the Justices who signed his Colegrove opinion first held that the dispute was governed by Wood v. Broom,$^{18}$ and in Wood the Supreme Court had not questioned the jurisdiction, but on the contrary had reversed the district court on the merits. In any event, the matter has often been litigated without serious doubt as to jurisdiction. After all, the claim is that the equal protection clause prohibits geographical discrimination in the allocation of representatives in the state legislature. That such a claim is within the subject matter committed to the Court seems beyond dispute.

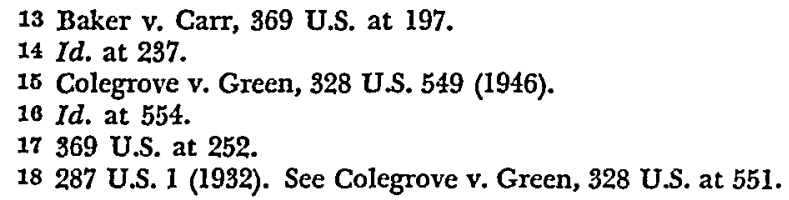


As to the justiciability of the questions, the easy answer is that in several cases such matters have been adjudicated and decided upon the merits. Again, there is language to the contrary in the Frankfurter opinion in Colegrove, and language in South $v$. Peters ${ }^{19}$ which could be taken as indicating that the issues were non-justiciable, but the stark fact stands out that in MacDougall $v$. Green ${ }^{20}$ a very similar issue was adjudicated, and the disposition of causes in several other cases was antithetical to the suggestion that the questions are beyond judicial determination. ${ }^{21}$

In a separate opinion, Mr. Justice Stewart stated that the majority opinion went no further than holding simply that the matters involved in Baker $v$. Carr constituted a subject matter within the jurisdiction of the district courts, and that they were not non-justiciable "political questions," saving until the time at which there might be occasion to review the case on the merits the question of the extent to which the equal protection clause prohibits rural bias in legislative apportionment. ${ }^{22}$ If $\mathrm{Mr}$. Justice Stewart was accurate in this view of what the majority opinion held, there can be little quarrel with its correctness. In the context of the Baker case, however, it would be idle to demonstrate the justiciability of the controversy by showing that such controversies have often been decided on the merits, if in this process it becomes apparent that they were all decided in a manner adverse to the contention of the Baker plaintiffs. So, as Mr. Justice Brennan proceeded to distinguish the fourteen pertinent Supreme Court decisions since $1932,{ }^{23}$ ostensibly simply to show that they do not hold the issues non-justiciable, he used consummate care to avoid the implication that in any of them the Court had decided the merits of the constitutional right asserted in the case at bar. At the start it should be stated that these decisions cannot be distinguished on the facts alleged by the plaintiffs, for not only have nearly identical claims been before the Court ${ }^{24}$ on

19339 U.S. 276 (1950).

20335 U.S. 281 (1948).

21 E.g., Wood v. Broom, 287 U.S. 1 (1932). See also Smiley v. Holm, 285 U.S. 355 (1932); Koenig v. Flynn, 285 U.S. 375 (1932); Carroll v. Becker, 285 U.S. 380 (1982).

22369 U.S. at 265.

23 See cases cited in note 11 supra.

24 The facts in Colegrove v. Barrett, 330 U.S. 804 (1946), are very similar, if not identical. In the Barrett case the statute under attack was the Illinois Apportionment Act of 1901 [ILL. Rev. Stat. ch. 46, $\$ 150,152$ (1961)] enacted the same year that the Tennessee act under attack in Baker $v$. Carr was passed, and based upon the same census (that of 1900). The Illinois provision was, therefore, forty-six years old at the time the Barrett case brought, while in Baker $v$. Carr the Tennessee act was sixty. In Illinois, by 1940, the largest senate district was roughly sixteen times as populous as the 
several occasions, but the precise statute challenged as unconstitutional in Baker was before the Court in an earlier case. ${ }^{25}$

Wood v. Broom ${ }^{26}$ was disposed of in a footnote quoting from Mr. Justice Rutledge's opinion in Colegrove $v$. Green, to the effect that the Wood case decided no constitutional questions, but "the Court disposed of the cause on the ground that the $1929 \mathrm{Re}$ apportionment Act ... did not carry forward the requirements of the 1911 Act ... , and declined to decide whether there was equity in the bill."27 The Brennan opinion continued, "We agree with this view of Wood v. Broom." 28 Certainly from the vantage point of 1946, when Mr. Justice Rutledge delivered his opinion in Colegrove, Wood v. Broom was not strong precedent, inasmuch as the Court did not discuss the point of an equal protection right to equality of representation unaided by an act of Congress. The claim was grounded upon this contention, however, as well as upon the statute, a fact noted by Mr. Chief Justice Hughes in his opinion. ${ }^{20}$ This was explained away by the Colegrove plaintiffs as illustrating the principle that where relief is sought on two grounds and granted on one of them, and the ground upon which relief is granted proves to be erroneous, the appellate court will

smallest, with one senator elected from each district. In Tennessee, house and senate districts are combined for application of Mr. Justice Clark's representative quotient. By this method, he determined that the differences were in the order of 100 to 1 . In South v. Peters, however, the differences were conceded to be of that order. See text infra at 723-24.

25 Kidd v. McCanless, 352 U.S. 920 (1956). The McCanless case was an appeal from the Supreme Court of Tennessee. See text infra at 736.

20287 U.S. 1 (1932).

27328 U.S. at 565. It should be noted, however, that $\mathrm{Mr}$. Justice Rutledge placed his willingness to dismiss for lack of equity on the ground that the elections were to be held shortly and it was doubtful if effective relief could be given. In Wood $v$. Broom, the four Justices who voted to reverse and dismiss the bill for want of equity were dealing with a case in which relief had been granted, and in which there was a permanent injunction outstanding. Accordingly, there was no problem about the efficacy of relief. Nor was there, presumably, any feeling that the relief granted was in any way inappropriate or would create local chaos. The same relief had been granted in the previous term in Smiley $v$. Holm, Koenig $v$. Flynn, and Carroll v. Becker. In this connection, it is interesting to note that, after the granting of the injunction below, the defendants applied to $\mathrm{Mr}$. Justice Cardozo for supersedeas. The application was denied in an opinion which pointed out that both the laws of Mississippi and those of the United States provided for special elections to fill vacancies, and, as a consequence, it could be said that no irreparable harm would result from permitting the injunction to stay in force until the matter could be settled on the merits. See Record, p. 35, Wood v. Broom, 287 U.S. 1 (1932).

28 Baker v. Carr, 369 U.S. at 234 n.59.

20 Wood v. Broom, 287 U.S. at 4: "The alleged grounds of invalidity were that the act violated Art. I, $\S 4$, and the Fourteenth Amendment, of the Constitution of the United States, and $\S 3$ of the Act of Congress of August $8,1911 \ldots$. 
reverse the judgment without considering the other ground. It is said there that the Lawyers Edition headnote to Wood v. Broom explains the case in that fashion. ${ }^{30}$ Of course the headnote referred to says no such thing. It says, instead, that where relief is granted on a ground which on appeal proves to be erroneous, the Court will refuse to rule on the question of whether or not the plaintiff would have been entitled to relief had the ground on which it had been granted been upheld on appeal. ${ }^{31}$ This is an accurate statement of Mr. Chief Justice Hughes's opinion.

In Colegrove v. Green, said Mr. Justice Brennan, "the Court followed [Smiley v. Holm, ${ }^{32}$ Koenig v. Flynn, ${ }^{33}$ and Carroll $v$. $\left.B e c k e r^{34}\right]$... although over the dissent of three of the seven Justices who participated in that decision." He went on to say that "indeed, the refusal to award relief in Colegrove resulted only from the controlling view of a want of equity." 35

The first of these statements is somewhat misleading. The Court did not follow the precedents in Smiley, Koenig, and Carroll. In those cases the constitutional issue was decided on the merits and relief was granted. In Colegrove v. Green, the most that can be said is that four members of the Court expressed an opinion that the issues were justiciable. Though Mr. Justice Rutledge expressed his agreement with Justices Black, Douglas and Murphy in their view that the Court was empowered to decide the constitutional question, he expressly refused to reach it, for his view of dismissal for want of equity was one of avoiding unnecessary constitutional decisions. ${ }^{36}$ So while four members of the seven-man Court thought the issues were justiciable, the Court did not hold them to be so, nor did it follow the precedents said to demonstrate their justiciability. It dismissed the appeal. Since the persuasion of Justices Black, Douglas, Murphy and Rutledge on this issue had no connection with the outcome of the case, it remains what it was-an expression of opinion by a minority of the full Court.

$30 \mathrm{~S}$ Brief for the Better Government Association as Amicus Curiae, p. 69, Colegrove v. Gree.x, 328 U.S. 549 (1946).

31 See 77 L. Ed. 131 (1932), headnote 2: "Where it appears that the ground on which injunction was granted below does not exist, the Supreme Court of the United States will not consider the right of the complainant to relief in equity upon the allegations of the complaint or the justiciability of the controversy, assuming such ground to exist."

32285 U.S. 355 (1932).

33285 U.S. 375 (1932).

34285 U.S. 380 (1932).

35 Baker v. Carr, 369 U.S. at 232, 234.

36 See Colegrove v. Green, 328 U.S. at 564. 
The second statement is simply incorrect. Since Mr. Justice Rutledge did not reach the issues of substantive constitutional law, there is no warrant for saying that, absent the prevailing view of want of equity, relief would have been afforded to the Colegrove plaintiffs. All that can be said along this line is that, absent the prevailing view of want of equity, the claim of constitutional deprivation would have been decided. Mr. Justice Rutledge gave no hint as to which way he would vote on such a claim. As a consequence one cannot say whether or not relief would have been granted.

Having thus disposed of the two cases in which there were signed opinions, Mr. Justice Brennan turned to the per curiam decisions. Of the first of these, Cook v. Fortson (Turman v. Duckworth), ${ }^{37}$ he said that the appeals there were dismissed as moot. In this he was correct, although in disposing of them the Court cited Colegrove v. Green as well as United States v. Anchor Coal Co. ${ }^{38}$ "MacDougall v. Green," 39 he continued, "held only that in that case equity would not act to void the State's requirement that there be at least a minimum of support for nominees for state-wide office, over at least a minimal area of the State."40 MacDougall arose out of the efforts of the Progressive Party to run a slate of electors for President and Vice President of the United States, as well as candidates for local offices, in Illinois in the election of 1948. Under applicable provisions of the Illinois election laws, new parties were required to file a petition containing the signatures of twenty-five thousand qualified voters, including at least two hundred qualified voters from each of at least fifty of the state's one hundred and two counties. The Progressive Party submitted such a petition with the requisite total number of signatures. The petition did not meet the requirement of two hundred each from at least fifty counties, and, as a consequence, the election officials refused to print the names of its candidates and electors on the official ballot. MacDougall involved a suit brought before a threejudge district court to require them to do so. The court dismissed the cause for want of jurisdiction, citing no precedents, and the plaintiffs appealed to the Supreme Court. In a short per curiam

37329 U.S. 675 (1946).

38279 U.S. 812 (1929) (on the subject of mootness). The Anchor Coal case was not exactly in point, but made reference to dismissals of appeals for mootness. In the case itself there was an outstanding injunction and the court held that the proper disposition was to reverse the lower court and vacate its judgment.

39335 U.S. 281 (1948).

40 Baker v. Carr, 369 U.S. at 234-35. 
opinion the Supreme Court affirmed. The opinion read, in part, as follows:

"To assume that political power is a function exclusively of numbers is to disregard the practicalities of government. Thus, the Constitution protects the interests of the smaller against the greater by giving in the Senate entirely unequal representation to populations. It would be strange indeed, and doctrinaire, for this Court, applying such broad constitutional concepts as due process and equal protection of the laws, to deny a State the power to assure a proper diffusion of political initiative as between its thinly populated counties and those having concentrated masses, in view of the fact that the latter have practical opportunities for exerting their political weight at the polls not available to the former. The Constitution - a practical instrument of government-makes no such demands on the States." 41

Mr. Justice Brennan's characterization of the case, if the phrase in his opinion indicating that in MacDougall the Court "held only that in that case equity would not act" 42 can be interpreted as suggesting that the cause was disposed of by reference to some equitable consideration such as time, relief, or the like, is clearly wrong. We know this, first, because of the clear and unambiguous language of the opinion: "The Constitution . . . makes no such demands on the States." ${ }^{43}$ We know it also because Mr. Justice Rutledge wrote a concurring opinion in which he reiterated his view that constitutional questions should be avoided where possible and indicated that he would follow the same procedure he had suggested in Colegrove and dismiss the appeal on the discretionary ground of want of equity. He saw in the case the same factors of time and doubt about the ability to give effective relief as he had seen in Colegrove.44 The difference between Colegrove v. Green and MacDougall v. Green was in the fact that the latter was heard by a full Court and the majority did not need the vote of Mr. Justice Rutledge. Rutledge was under no doubt that the case was decided on the merits and his concurrence was written to demonstrate his disagreement.

The MacDougall majority cited Colegrove v. Green and Cole-

41 MacDougall v. Green, 335 U.S. at 283-84.

42 Baker v. Carr, 369 U.S. at 234.

43 MacDougall v. Green, 335 U.S. at 284. (Emphasis added.)

44 To avoid confusion, Colegrove has been used to designate Colegrove v. Green, Barrett to designate Colegrove v. Barrett, and MacDougall for MacDougall v. Green. 
grove v. Barrett as authority for the proposition that the Constitution makes no demand on the states that they refrain from assuring a proper diffusion of political initiative as between their thinly-populated counties and those with concentrated masses. ${ }^{45}$

The Barrett case was, in a way, a non-identical twin of Colegrove v. Green. They were successive steps in the long legal battle to force the state of Illinois to reapportion. The Illinois General Assembly reapportioned the legislature and congressional districts in the year 1901. For the next three censuses it did nothing, and, because of the very rapid growth of the city of Chicago, congressional, state senate and General Assembly districts became greatly different in population. Efforts to enlist the aid of the Illinois courts to require the General Assembly to reapportion state senate and General Assembly districts were three times rejected by the state supreme court, which refused mandamus to compel reapportionment, ${ }^{46}$ refused to declare invalid acts adopted by the General Assembly on the alleged ground that the members of the General Assembly did not constitute a de jure legislature, ${ }^{47}$ and refused to unseat members in a quo warranto proceeding. ${ }^{48}$ In 1931, the General Assembly enacted a new congressional apportionment act. ${ }^{40}$ Although the new act embodied smaller differentials in representation ratios than existed by this time under the act of 1901, the districts were nonetheless far from equal in population, the largest containing 541,785 inhabitants and the smallest 158,738, a difference of roughly three to one. ${ }^{50}$ An action was brought to enjoin the expenditure of money to hold the congressional election of 1932 under the provisions of the act of 1931, and the state supreme court sustained the contentions that the act violated both the Congressional Apportionment Act of 1911 , and the provisions of the constitution of Illinois. ${ }^{51}$ To the horror of the plaintiffs, however, it went on to hold that since the act of 1931 was unconstitutional and void, the applicable provision was the act of 1901, under which the districts varied from 914,053 to 112,116 , a difference of over eight to one. ${ }^{52}$ An action

15 MacDougall v. Green, 335 U.S. at $283-84$.

46 Fergus v. Marks, 321 Ill. 510, 152 N.E. 557 (1926). See SEArs, Methods of ReapporTIONMENT 4-I1 (1952). Other Illinois cases failing to grant relief are listed in the complaint in Colegrove v. Barrett (unreported), No. 46, C 1946, N.D. Ill.

47 Fergus v. Kinney, 333 Ill. 437, 164 N.E. 665 (1928).

18 People ex rel. Fergus v. Blackwell, 342 Ill. 228, 173 N.E. 750 (1980).

48 LAWS OF the STATE of IlLiNoIs 545 (1931).

50 See Moran v. Bowley, 347 Ill. 148, 150, 179 N.E. 526, 527 (1932).

51 Ibid.

62 See Colegrove v. Green, 328 U.S. at 557. 
was then brought seeking to invalidate the 1901 act. Meanwhile the Supreme Court of the United States decided Wood v. Broom. The Illinois supreme court then held that the federal ground which sustained its earlier decision was withdrawn by that case and, reversing itself on the state constitutional ground, refused to interfere..$^{53}$ It was at this point that Colegrove v. Green ${ }^{54}$ was filed, seeking the aid of the federal courts. After losing in that case by a three-one-three decision, Colegrove v. Barrett ${ }^{55}$ was brought, attacking in the federal courts the Illinois state senate apportionment. One may well ask how it could be assumed by Illinois franchise reformers that a suit attacking the validity of the state senate apportionment would be successful where attack on congressional apportionment had failed. It must be remembered, however, that in Colegrove v. Green they had lost by one vote, and that vote was cast on the ground of lack of equity stemming at least partially from the individual facts of time. It must also be remembered that Colegrove v. Green mustered no majority of a full court and that, by the time Colegrove v. Barrett was filed, Mr. Chief Justice Vinson and Mr. Justice Jackson were sitting. The district court dismissed for want of equity, without opinion, presumably relying upon the ground given in Colegrove v. Green. On appeal the Supreme Court dismissed for want of a substantial federal question, Mr. Justice Rutledge putting his vote to dismiss on the ground that the Court had refused to rehear Colegrove $v$. Green and to hear Cook v. Fortson (Turman v. Duckworth).

Mr. Justice Brennan withheld discussion of the Barrett case until last in disposing of the per curiam decisions, and brushed it off with the following observation: "Lastly, Colegrove v. Barrett . . . , in which Mr. Justice Rutledge concurred in this Court's refusal to note the appeal from a dismissal for want of equity, is sufficiently explained by his statement in Cook v. Fortson, supra: "The discretionary exercise or non-exercise of equitable or declaratory judgment jurisdiction .... in one case is not precedent in another case where the facts differ." "5z The statement is no doubt true in an abstract sense, though one would suppose that if the difference in fact alluded to relates to one of the facts on which the first decision turned, it is true of all precedents.

\footnotetext{
53 Daly v. County of Madison, 378 Ill. 357, 38 N.E.2d 160 (1941).

54328 U.S. 549 (1946).

55 No. 46, C 1946, N.D. Ill. (unreported).

56329 U.S. 675 (1945).

57 Baker v. Carr, 369 U.S. at 236-37.
} 
In the context of the statement in his Cook (Turman) ${ }^{58}$ opinion, what Mr. Justice Rutledge meant was undoubtedly that since the actual decision in Colegrove v. Green turned upon questions of timing and the efficacy of equitable relief in that case-his being the deciding vote-it was no bar to the consideration of the constitutional questions in Cook (Turman), and further, that Cook (Turman), unlike Colegrove, did not deal with allocation of representatives among geographical subdivisions of the state; rather, it dealt with distribution of influence in the nomination of officers to be selected at large.

What relevance does the statement have, then, in the effort to distinguish the Baker case from the Barrett case? In the latter, the Supreme Court held that the dismissal of the bill by the district court presented no substantial federal question. Since the district court delivered no opinion, it is not apparent that the decision was based on the ground that there existed any special equity considerations such as lack of time to give adequate relief. The relief requested was substantially the same. On the constitutional level the cases present exactly the same issues and the discrepancies in representation ratios complained about in Barrett were only slightly smaller than those complained of in Baker.50 In short, if it is conceded that differences in facts can take the teeth out of earlier decisions, Mr. Justice Brennan failed to point out any differences in facts between Baker and Barrett which could be expected to accomplish that result. As a matter of fact, he suggested no differences at all.

At this point it is useful to go back and place the decisions from Colegrove v. Green through MacDougall v. Green in orderly sequence to see if it is possible to trace the Court alignment on the issues involved. As we have seen, in Colegrove v. Green no questions of constitutional law were finally decided. No questions of any sort were decided by a majority of the full Court. Soon after the qualification of Mr. Chief Justice Vinson and Mr. Justice Jackson's return to the Court, an effort was made to reopen the case so that the issues could receive the attention of the full Court. In the meanwhile, the appeals in Cook v. Fortson (Turman v. Duckworth) were filed. The motion for rehearing in Colegrove v. Green was heard and disposed of by the same seven members who had sat on that case, the Chief Justice and Mr. Justice Jack-

58 Cook v. Fortson (Turman v. Duckworth), 329 U.S. 675 (1946).

50 See note 24 supra. 
son taking no part. Mr. Justice Rutledge was of the opinion that the petition for rehearing should be granted and the case set down for argument with Cook (Turman). He did not consider the latter obviously moot and apparently thought a consideration of the three cases together by the full Court would serve to clear up the fog produced by the various opinions of the "bobtailed" Court in Colegrove v. Green.$^{60}$ His reasons are obscure but hinted at by his Colegrove opinion. He was of the opinion that the issues were justiciable, and may have wished to have that issue ruled upon by the full Court to avoid the effect of the "political question" language in the Frankfurter opinion on subsequent efforts to raise these issues. If this was his motive, subsequent events suggest that perhaps he was correct. In any event it is hard to suggest other motives in view of his desire to dispose of the case in the first instance on the ground that the time factor made relief of doubtful efficacy, and his statement that wherever possible the substantive constitutional question should be avoided. It had been avoided in Colegrove v. Green, and the mootness of Cook (Turman) was certainly plausible enough to provide as sensible an "out" as the time considerations were in Colegrove.

The views of the three Colegrove dissenters are also of interest. Since Mr. Justice Rutledge favored rehearing, and the petition for rehearing was heard by only seven members of the Court, it was within their power to reopen the case. They did not, and the two motions for rehearing were denied. ${ }^{61}$ In Colegrove $v$. Barrett, Mr. Justice Rutledge said that he concurred in the dismissal in view of the fact that the Colegrove petition for rehearing had been denied and the appeals in Cook (Turman) had been dismissed. ${ }^{62}$ Viewed from the time of occurrence, it might be thought that the four who failed to join the Frankfurter opinion in Colegrove v. Green had given up, and the matter was settled. From their opinions in MacDougall, however, it seems probable that the members of the original Colegrove Court remained unchanged in their positions and that the three dissenters were engaged in what may be called tactics of dissent. They must have assumed that their views would not find acceptance among a majority and were therefore reluctant to risk the possibility that a full-scale hearing of the issues, followed by an opinion on the

60 The term "bobtailed" is borrowed from the Clark opinion in Baker v. Carr, 369 U.S. at 252.

61329 U.S. 825 (1946); id. at 828.

62329 U.S. 675 (1946). 
merits, would give majority support to the views expressed by Mr. Justice Frankfurter in his Colegrove opinion. In MacDougall, of course, this is exactly what happened. Mr. Justice Rutledge won his point, however, on the issue of justiciability. The Court heard the cause on the merits, and, citing Colegrove and Barrett, reached a decision adverse to the views of Justices Black, Douglas, and Murphy. The decision in MacDougall is important, then, not only because it decided the constitutional issues as posed by the facts before the Court in that case, but because presumably it casts some light upon the views of the majority of the full Court on the meaning of the dismissal of the appeal in Barrett as presenting no substantial federal question, and follows the view of the adherents to the Frankfurter opinion in Colegrove that the equal protection clause does not require that political influence be apportioned among the state's geographical subdivisions on a per capita basis, without regard to density of population. In summary, the dissenters had lost on their assertion of a constitutional requirement of "one man-one vote." They had won on their view that the issue should be heard on the merits. One might ask why Mr. Justice Frankfurter joined in deciding the merits, but it will be remembered that he also would have decided the merits in Colegrove.

At this point Mr. Justice Murphy and Mr. Justice Rutledge left the Court and were replaced by Justices Clark and Minton, an event which could not adversely affect the majority but might serve to increase its margin. That term brought the appeals in South v. Peters ${ }^{63}$ and in Tedesco v. Board of Supervisors. ${ }^{64}$ South v. Peters was a suit in equity brought in the Federal District Court for the Northern District of Georgia seeking to restrain the operation of the Georgia primary law in the primary election which was to be held in 1950 to nominate Democratic candidates for the general election to be held later in the same year. Under the Georgia act in question a number of unit votes was assigned to each county in the State, ranging from six in the eight most populous counties down to two for some of the smaller counties. In each county the votes were counted and the person receiving the majority was credited with all of the unit votes in that county. The case was similar to the apportionment cases because it was alleged that the assignment of six unit votes to Fulton County, with its 473,572

63 339 U.S. 276 (1950).

64339 U.S. 940 (1950). 
inhabitants, and two to Chattahoochee, with fewer than 2,000, was a violation of the equal protection clause in that it amounted to a debasement of the votes of the residents of Fulton County, it being said that a vote in Fulton County was worth $1 / 122$ of a vote in Chattahoochee ${ }^{66}$ in terms of the influence it had on the outcome of the election. The Georgia statute had other evils. From the viewpoint of the individual voter, not only might his vote be counted as $1 / 122$ of his counterpart in another county, but it might be counted for the person he voted against. Similar to the electoral college system, the Georgia unit vote method left the possibility that a candidate might be nominated when he had received less than a plurality of the votes cast at the primary election.

In a per curiam opinion a divided district court held that the system did not violate the Constitution. ${ }^{67}$ It read the dismissal of the bill in Wood $v$. Broom, over contentions made under the equal protection clause, as having the effect of denying relief under the fourteenth amendment, despite the fact that the point was not specifically discussed in the majority opinion. It read the minority opinion in Wood as "put on the ground that the matter was political and not of equitable cognizance." The subsequent cases, said the court, followed Wood; they did not overrule it.

Judge Andrews dissented. ${ }^{68} \mathrm{He}$ saw the issue in South as one of whether one man's vote should be counted more than another's. He read the Colegrove case as depending upon difficulties in fashioning relief and not standing upon the broader ground of absence of jurisdiction to correct a political wrong. He took the Allwright ${ }^{69}$ case as settling the question of whether the right to vote in a primary election which is an integral part of the state's election machinery is within the constitutional protection against discriminations in matters of the franchise, and Chapman v. King ${ }^{70}$ as holding that the Georgia primary elections were an integral part of the election machinery. South, he said, was different from Colegrove because it required no future legislation and presented no problems in fashioning methods of relief. It was further dis-

65 See South v. Peters, 339 U.S. 276, 278 (1950) (Douglas, J., dissenting).

66 Mr. Justice Douglas speaks of the difference as "over 120." The figure 122 to 1 comes from Judge Andrews' dissenting opinion in the district court. See $89 \mathrm{~F}$. Supp. 672, 683 (N.D. Ga. 1950). Judge Andrews speaks of the average difference as 11 to 1.

67 South v. Peters, 89 F. Supp. 672 (N.D. Ga. 1950).

$68 I d$. at 681 .

69 Smith v. Allwright, 321 U.S. 649 (1944).

70154 F.2d 460 (5th Cir. 1946). 
tinguished by the fact that in South the plaintiffs did not complain of their county's lack of representation in the General Assembly. They simply asserted a constitutionally protected right to vote for their nominee for United States Senator, and to have their votes counted like all other votes.

The Supreme Court affirmed the district court with this comment: "Federal courts consistently refuse to exercise their equity powers in cases posing political issues arising from a state's geographical distribution of electoral strength among its political subdivisions. See MacDougall v. Green ... ; Golegrove v. Green ... ; Wood v. Broom . . . ; cf. Johnson v. Stevenson . . . ."71

Mr. Justice Douglas, joined by Mr. Justice Black, wrote a dissenting opinion. He relied upon Colegrove v. Green and MacDougall v. Green, without mentioning the Wood case. The first, he said, depended upon Mr. Justice Rutledge's vote, and was decided upon special facts of time and the uncertainty about the effectiveness of the relief sought. Those factors, he demonstrated, were not present in South. Over two months remained before the scheduled primary. MacDougall he apparently interpreted as resting upon the question of justiciability: "And in MacDougall v. Green .... , the Court on a closely divided vote refused to interfere with the provisions of the Illinois law governing the formation of a new political party. There is no such force in the argument that the question in the present case is political and not justiciable." 72

Mr. Justice Brennan said that South v. Peters "appears to be a refusal to exercise equity's powers." 73 Such a refusal is not explainable in terms of the sort of problem which prompted Mr. Justice Rutledge to put his vote in Colegrove on the ground of want of equity. The Court described the class of cases in which federal courts "consistently refuse to exercise their equity powers," 74 and the class is stated to encompass "cases posing political issues arising from a state's geographical distribution of electoral stength among its political subdivisions."75 For examples of the application of this principle one is referred to Wood $v$. Broom, Colegrove $v$. Green, and MacDougall v. Green. Wood, if it has any relevance to the constitutional question, must have decided it on the merits,

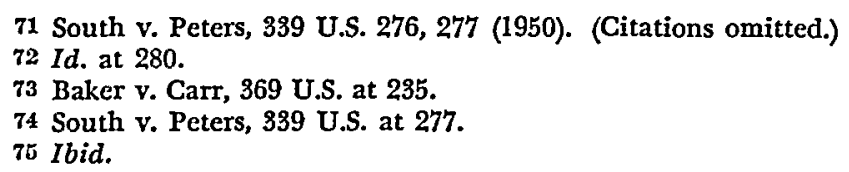


for as we have seen the Court refused to dispose of the case on the ground of want of equity, and refused to say whether or not the issues would have been justiciable had there been a statutory requirement of equality of population among districts. Since the failure to uphold relief granted below in the face of a claim of entitlement to it under the fourteenth amendment was not explained in the majority opinion in Wood, it is of course not beyond argument that the Court was of the opinion that a claim under the fourteenth amendment is not justiciable, whereas a claim under the statute might be, but such a holding would be, to all intents and purposes, a holding that there is no requirement of equality under the naked fourteenth amendment, but there is a power in Congress to provide one. In Colegrove, the deciding vote was cast on want of equity in the particular bill, but three of the four Justices voting to affirm placed their votes on the merits under Wood v. Broom, as well as upon want of equity, the discussion of the second ground demonstrating, however, that the want of equity rested upon the opinion that the entire class of cases was not proper grist for the judicial mill. In MacDougall, the merits were heard and determined.

Certainly Mr. Justice Brennan was correct in stating that the South case cannot be looked upon as one in which the Court had no jurisdiction over the subject matter. The writer suggests that it is also impossible to consider it as one dismissed because of such factors as timing or special problems of giving relief. The primary election in question was two months away and the relief sought did not require anything but an order to the election officials to count the votes without debasing them or allocating all votes from a county to the candidate receiving a plurality within the county. Whatever the reason for non-intervention, the Court announced adherence to such a policy in equity cases involving "political" issues arising out of geographical allocation of electoral strength. Just why the language of the short statement handed down in the South case returned to that of abstention from adjudicating "political" issues ${ }^{76}$ rather than the plain language of absence of constitutional requirement employed in MacDougall ${ }^{7 \pi}$ is not apparent. The language seems to be a return to the Frankfurter position in Colegrove, that these political controversies are things that equity courts are well out of, whether or not they might be of the opinion

76 See text at notes 74-75 supra.

77 See text at note 40 supra. 
that there is alleged some evil which might abstractly be considered violative of the principles of equality suggested by the general provisions of the Constitution. The references to the previous cases indicate that the Court is not modifying these decisions, but may suggest that it is less willing to say that the Georgia legislature had achieved a "proper distribution" of political initiative than it was in speaking of the Illinois statute. On its facts, then, South is a much stronger case than MacDougall, but it does employ the language of discretion, rather than the language of power, or of constitutional substance.

The appeal in Tedesco v. Board of Supervisors ${ }^{78}$ was decided a week after the Court delivered its opinion in South. Tedesco was a case in which plaintiffs contested the validity of the new charter of the city of New Orleans. Under the old charter the city was governed under a so-called commission plan. A mayor and four commission councilmen were elected at large. After their election and qualification the subject-matter functions of the city government were parcelled out among the councilmen, each becoming administrative head of one of the city's departments. The new charter added three members to the commission council and provided that the seven commission councilmen should be elected from districts, retaining the at-large election of the mayor. The election districts named were the so-called "municipal districts" of the city, which varied in population from 8,508 to 48,020 . The complaint charged that the new charter was unconstitutional in that it subjected the plaintiff to government by persons for whom he was not permitted to vote, and in that residents of the less populous districts were given greater representation in the commission council than those who resided in those more heavily populated. Since the claim was joined with a variety of allegations of unconstitutionality under the Louisiana constitution, the bill was brought in the state courts. The Court of Appeal for the Parish of New Orleans disposed of the state claims and then, after a review of the United States Supreme Court cases, held that the charter did not violate the fourteenth amendment. Expressing some doubt that discrimination of any sort other than violation of the fifteenth or nineteenth amendments was prohibited under the Constitution, it said that, in any event to show constitutionally prohibited discrimination without demonstrating violation of the fifteenth or nineteenth amendment, it would be necessary to show

78339 U.S. 940 (1950). 
that the plan under attack did not admit of benign construction. It added that possible benign legislative motives had been suggested and therefore in the case at bar no "unwarranted" and hence unconstitutional discrimination had been shown. ${ }^{79}$

The appeal to the Supreme Court was dismissed for want of a substantial federal question. ${ }^{80}$ The Court was unanimous; there was no written opinion, and no cases were cited. Mr. Justice Brennan interpreted Tedesco as holding "solely that no substantial federal question was raised by a state court's refusal to upset the districting of city council seats, especially as it was urged that there was a rational justification for the challenged districting."

What Mr. Justice Brennan meant by this is rather obscure. Does Tedesco depend upon the fact that it is an appeal from a state court's decision? There is no hint in the lower court opinion of any independent state ground for the decision. The federal constitutional issue was squarely faced and decided. The allegation was that a citizen living in one district of 8,508 was represented by one commission councilman and his fellow citizen in another district containing over five times as many inhabitants was also represented by one member, a difference in representation ratio of over five to one. The court's answer was: "We conclude that there is nothing in the statute violative of ... any of the provisions of the Federal Constitution nor the amendments thereof." ${ }^{82}$ Nor was there any suggestion in Tedesco that the state court was either unable or unwilling to grant the relief asked, had it been of the opinion that the new charter violated the provisions of the Constitution. Indeed, the court stated that, following the lead of the Supreme Court of Louisiana, it would "pretermit" the "various pleas and exceptions," and pass directly to the merits because it was desirable that the issues be promptly and finally settled, so that the city could commence operations under its new charter. ${ }^{83}$ Can it be that a decision on the merits disposing of a claim under the United States Constitution, in a case in which the state court dispenses with formalities and decides the merits because it wants an early and final determination, presents no substantial federal question, independent of the merits of the particular claim? The

79 Tedesco v. Board of Supervisors of Elections for Parish of Orleans, 43 So. 2d 514, 518 (La. Ct. App. 1949).

80 Tedesco v. Board of Supervisors, 399 U.S. 940 (1950).

81 Baker v. Carr, 369 U.S. at 235.

8243 So. 2d 514, 519 (La. Ct. App. 1949).

83 Id. at 516. See City of New Orleans v. Board of Supervisors of Elections for Parish of Orleans, 216 La. 115, 43 So. 2d 237 (1949). 
writer suggests that the case cannot turn upon the fact that the case was originally decided by a state tribunal. Relations between federal and state courts may require the federal courts to refrain as much as possible from ordering state courts to provide remedies they do not choose to provide; it certainly does not require that the Supreme Court leave the state without a solution as to constitutional issues until someone brings another suit in a federal court.

Nor does the fact that Tedesco involves the representation of citizens on a local council commission serve to distinguish the case. If a citizen has a right to equal representation in the state legislature, can it be that he has no similar right to representation in the legislature of the local jurisdiction in which he lives? The writer should have thought that this question was decided in the negative in 1915, in Myers $v$. Anderson ${ }^{84}$ There the defendant argued that the fifteenth amendment did not apply to municipal elections, but he lost. Can it be that the fourteenth amendment is any less universal in its application to the various levels of state and local government?

In regard to the rational justification of the challenged districting, it should be mentioned initially that prior to the enactment of the new charter amendments in 1948, the members of the commission council were all elected at large. Two arguments were made against the change to district elections. The first was to the effect that mere election from districts made the amendment unconstitutional. The state court made short shrift of this, pointing out that the members of many of the state's institutions of government were selected from districts, including the members of the state supreme court. The other argument was inequality in the population of the districts. To this the court had said that not difference but "unwarranted" discrimination would have to appear. It went on to say that such unwarranted discrimination, if shown, would invalidate the statute. It then inquired into the "real reason" for the passage of the legislation. Whatever that may have been, said the court, "whether the reason was political, or whether it was punitive, we must assume that the legislature acted properly and on sound reason." 85

Continuing, the state court made the following statement,

84238 U.S. 368 (1915).

85 Tedesco v. Board of Supervisors of Elections for Parish of Orleans, 43 So. 2d 514, 518 (La. Ct. App. 1949). 
resulting in Mr. Justice Brennan's qualification dealing with "rational justification for the challenged districting."

"Counsel for defendants call attention to the fact that at the present time no one of the Commissioners was chosen from the downtown or lower districts of the City, and they call attention to the further fact that there are divergent groups, social and otherwise, who live in the various districts and counsel suggest that possibly a realization of the fact that some of these downtown groups are not represented on the present Commission Council led the Legislature to decide that some method should be adopted under which each of the various districts, however located, would be represented. We do not know that this was the reason, but it is a possible reason, and who can say that it is not a sound reason. If it was, then there was no unfair discrimination."

This is plainly nothing more than an example of the time-honored statement that courts will presume that the legislature has done its duty and leave to the plaintiffs the task of demonstrating otherwise. Since "certain groups, social and otherwise" are everywhere present in unlimited variations, the possible rational base for the discrepancies "urged" upon the Court in Tedesco is present in all apportionment schemes. If its urging in Tedesco distinguishes that case from the rest, it is a triumph of ritual over substance.

Before further changes in the personnel of the Court, three more apportionment cases were decided. The first of these was Remmey v. Smith. ${ }^{87}$ Remmey was a suit in a federal district court to challenge the Pennsylvania Apportionment Act of 1921, as applied in 1951, and to compel the legislature to reapportion the state in a constitutional manner. The district court dismissed the bill. The majority, in an opinion by Judge Biggs, said that even where the apportionment in the selection of national representatives was involved, the Supreme Court had held that the issues were "of a peculiarly political nature and therefore not meet for judicial determination." ${ }^{88} \mathrm{He}$ went on to say that, a fortiori, a court of the United States should not compel a state to apportion with respect to its own legislature. In a footnote he stated his opinion that the question of jurisdiction was not a settled one. ${ }^{80}$ In any event he thought that while the legislature was still in ses-

86 Id. at 519 .

87342 U.S. 916 (1952).

88 Remmey v. Smith, 102 F. Supp. 708, 710 (E.D. Pa. 1951).

89 Id. at 710 n.11. 
sion, and the 1950 census only a year old, the suit was prematurely brought, and for that reason he would dismiss it for want of equity. Judge Bard concurred, but went to the merits. ${ }^{90}$ Relying upon Minor v. Happersett, ${ }^{, 1}$ he took the discriminations prohibited by law to be only those based upon race, color, previous condition of servitude, and sex. The Supreme Court dismissed the appeal for want of a substantial federal question. It cited no cases. Mr. Justice Brennan limited the authority of the case to the ground given by the district court, the fact that the case was prematurely brought.

The second case was Cox v. Peters. ${ }^{92}$ Cox was an appeal from the Supreme Court of Georgia, which court had again upheld the county unit primary system under attack in South v. Peters..$^{93}$ The Georgia court had held that the right to vote in a primary election was not within the protection of the equal protection clause unless, under the rule of Classic, ${ }^{94}$ Allwright ${ }^{95}$ and Hern$d o n,{ }^{96}$ the primary is an integral part of the election machinery of the state. In Chapman v. King the Georgia primary had been held to be an integral part of the election machinery of the state, but the court took that case to be no longer applicable because of subsequent changes in the Georgia constitution. The Georgia law did not require the holding of a primary but specified how it must be held if the party decided to hold one. This fact, the court said, distinguished it from Classic, Allwright, and Herndon.

On appeal, the appellees recognized the thinness of this holding and did not rely upon it alone. ${ }^{97}$ They stated that they were not contending that the fifteenth amendment does not confer upon Negro citizens of Georgia the right to vote in the primaries, and rested their case on Minor v. Happersett and on the apportionment decisions. The appellants were anxious to frame the issue as one of whether primaries involve "state action" where they are regulated as to method but not required-with some warrant one would suppose, in view of the fact that the holding below was constitutionally feeble. They argued that since the Georgia court

$90 I d$. at 711 .

9188 U.S. (21 Wall.) 162 (1874).

02342 U.S. 936 (1952).

03339 U.S. 276 (1950).

94 United States v. Classic, 313 U.S. 299 (1941).

05 Smith v. Allwright, 321 U.S. 649 (1944).

96 Nixon v. Herndon, 273 U.S. 536 (1927).

07 See Statement Opposing Jurisdiction and Motion To Dismiss or Affirm, p. 4, Cox v. Peters, 342 U.S. 986 (1952). 
had decided upon that ground and had not considered the question of asserted right to equal influence, the Court should grant a summary reversal. Instead, it dismissed the appeal for want of a substantial federal question. When the decision came down, and the appellants noticed that no opinion had been written and no cases cited, they filed a motion for rehearing, praying that the Court at least give a statement of reasons because the decision might be taken as holding the fourteenth and fifteenth amendments do not apply to Georgia primaries at all. In aid of this motion the United States, through its Solicitor General, filed a memorandum in which the Solicitor General interpreted the Court's dismissal of the appeal not as approving the ground stated by the Georgia Supreme Court, that holding being clearly inconsistent with Classic, Allwright, and Herndon, but as following the apportionment cases. ${ }^{98}$ On the authority of Doremus $v$. Board of Education ${ }^{99}$ he argued that since the apportionment cases rested on absence of jurisdiction in the federal courts, there might still be jurisdiction in the state courts to adjudicate the issues. This motion was denied without comment or the citation of authority. Mr. Justice Brennan had this to say about the case: "And Cox v. Peters ... dismissed for want of a substantial federal question the appeal from the state court's holding that their primary elections implicated no 'state action.' "100 This is a factually accurate statement, of course, but the implication that Cox was dismissed because of the Court's views on the line to be drawn in defining "state action" in primaries is in this writer's opinion absurd. In

98 See Memorandum for the United States as Amicus Curiae in Support of the Petition for Rehearing, p. 6, Cox v. Peters, 342 U.S. 936 (1952): "We do not construe the Court's dismissal of the appeal as implicitly approving this ground of the State court's decision .... It would appear, however, that the dismissal of the appeal rests upon an application of the rule applied in South v. Peters, supra, as to the nonjusticiable character, so far as federal courts are concerned, of the political questions involved in the suit. Ordinarily, of course, the Court limits its review solely to a consideration of the precise federal question decided by the state court..... And where a state court decision is based on an erroneous federal ground, its judgment will be vacated and the cause remanded, notwithstanding that the state court might have based its decision on another ground, not considered and decided by it, which would have been adequate to support the judgment ....

"In this case, however, presumably because a similar controversy had been here two terms ago in South v. Peters, supra, the Court apparently pretermitted the immediate question decided by the Supreme Court of Georgia and went directly to what it deemed the ultimate issue in the case, namely, the merits of the claim of violation of federal constitutional rights."

99 Id. at 3. See Doremus v. Board of Educ., 342 U.S. 429 (1952).

100 Baker v. Carr, 369 U.S. at 235. 
the light of Classic, ${ }^{101}$ Allwright, ${ }^{102}$ and Herndon, ${ }^{103}$ and with the hindsight of Terry $v$. Adams, ${ }^{10 *}$ it is literally inconceivable that the Court should have thought that the Georgia court's holding on "state action" was correct. Undoubtedly the Solicitor General's interpretation of the dismissal was proper, that is, that where the overturning of the state court ruling would leave the case one of bald allegation of geographical differences in representation ratio, in no respect different from the allegations made in South $v$. Peters, the Court would not trouble itself to correct the state court on the ground of its decision where the result was clearly consistent with the Supreme Court precedents. ${ }^{105}$ Certainly the bar did not take Cox to hold what Mr. Justice Brennan implies that it held, since it was not so much as referred to in the briefs in Terry v. Adams, ${ }^{106}$ nor was it mentioned in any of the four opinions in that case, though if it was a precedent in the "state action" line of cases, it was obviously in want of distinguishing, for certainly the Georgia law governing primaries was much less private in its operation than was the Jaybird Association. Is it conceivable that had Cox been a plausible claimant under the fifteenth amendment, his claim would have raised no substantial federal question? And certainly if a right to equal geographical representation exists under the fourteenth, there is no way to distinguish the effect of such a holding, for "state action" is required to invoke both the fourteenth and fifteenth amendments.

If one assumes that Cox does not turn on this point, but on the law as announced in earlier apportionment cases, what does it add to the growth of the doctrine of judicial non-intervention? In the first place, it was an action at law for money damages, not a suit in equity. It could not then be resolved on a doctrine of discretionary power to refrain from exercising equity jurisdiction. If the non-intervention rule rested on article III, ${ }^{107}$ as was suggested by the Solicitor General, it could be explained as taking the matter away from all federal courts, including the Supreme Court, but such an interpretation runs squarely into the holdings in

101 United States v. Classic, 813 U.S. 299 (1941).

102 Smith v. Allwright, 321 U.S. 649 (1944).

103 Nixon v. Herndon, 273 U.S. 536 (1927).

104345 U.S. 461 (1953).

105 See note 98 supra.

100 See Petition for Certiorari, Brief for Petitioners, Brief for Respondents, and

Petition for Rehearing, Terry v. Adams, 345 U.S. 461 (1953).

107 U.S. CoNST. art. III, § 2. 
MacDougall v. Green ${ }^{108}$ and South v. Peters, ${ }^{109}$ where the language of the Court's opinions precludes an inference that the matter presents no case or controversy under the provisions of article III. The only basis of the decision consistent with all prior precedents is the ground that the unit system, already upheld on the merits by the federal district court in South v. Peters, in a decision affirmed by the Supreme Court, did not deprive the residents of the more populous counties of any right under the equal protection clause.

It is true that the method employed by Mr. Justice Brennan in disposing of the case cost nothing, for though it was left to depend upon a holding which was erroneous, and completely inconsistent with the Court's prior decisions, the question of "state action" in holding primaries was settled by the Terry"10 case, leaving Cox taken care of without risking future embarrassment to the Court. This is not so clear in Anderson v. Jordan, ${ }^{111}$ the third of the cases before the Court during this period. Anderson also arose in a state court. It was an action invoking the California Supreme Court's original jurisdiction in mandamus to force the legislature of that state to reapportion. The writ was denied per curiam, without opinion. ${ }^{112}$ The Chief Justice of California issued a certificate to the effect that the constitutional issue had been heard and decided. In the United States Supreme Court the appeal was dismissed for want of a substantial federal question. ${ }^{113}$ There was no opinion, but a reference to the same three cases referred to in South v. Peters: ${ }^{114}$ MacDougall v. Green, ${ }^{115}$ Golegrove v. Green, ${ }^{116}$ and Wood v. Broom. ${ }^{117}$ Mr. Justice Black and Mr. Justice Douglas dissented. ${ }^{118}$ In Anderson v. Jordan ${ }^{119}$ it was argued by the Attorney General of California that the certificate did not indicate that the federal issue was necessary to the decision, and Mr. Justice Brennan seized upon that to distinguish

108335 U.S. 281 (1948).

109339 U.S. 276 (1950).

110 Terry v. Adams, 345 U.S. 461 (1953).

111343 U.S. 912 (1952).

112 The decision of the Supreme Court of California is unreported. See Statement as to Jurisdiction, Anderson v. Jordan, 343 U.S. 912 (1952).

113 Anderson v. Jordan, 343 U.S. 912 (1952).

114389 U.S. 276 (1950).

115335 U.S. 281 (1948).

118328 U.S. 549 (1946).

117287 U.S. 1 (1932).

118 South v. Peters, 839 U.S. 276, 277 (1950).

119343 U.S. 912 (1952). 
Anderson from Baker. "[In Anderson v. Jordan] it was certain only that the State court had refused to issue a discretionary writ, original mandamus in the Supreme Court. That had been denied without opinion, and of course it was urged here that an adequate state ground barred this Court's review." ${ }^{20}$ Again the statement is factually accurate. If this was the ground on which the appeal was dismissed, however, how can the references be explained? All three of these cases came to the Supreme Court on appeal from lower federal courts and could not conceivably have had anything to do with independent state grounds. Further, during the same term of Court, action on Dixon v. Duffy $y^{121}$ was postponed for a second time to await more formal determination of the ground upon which the California Supreme Court had decided another original jurisdiction case, one involving habeas corpus. Certainly had the case turned upon the California Attorney General's contention that the chief justice's certificate was insufficient to show the necessity of the decision on the merits of the constitutional issue, some reference to the certificate dispute would have been included in the references. Instead, the Court dismissed the case with: "See MacDougall v. Green ...., Golegrove v. Green ..., Wood v. Broom ...." Dixon v. Duffy was cited to the Court by the appellants and it was urged that, if the certificate were deemed insufficient, appellants be given time to obtain a more lucid one. ${ }^{122}$ The next term of Court, with Mr. Justice Jackson dissenting, the judgment of the California Supreme Court in Dixon v. Duffy was vacated and the cause remanded so that the reasons of the California court could be made explicit. ${ }^{123}$ Could it be that Anderson, contrary to the then current practice of the Court in doubtful certificate cases, was dismissed on the ground that there was no adequate showing of a necessarily decided federal question, with no opportunity being given the appellants to obtain a more satisfactory certificate, and in a memorandum decision calling attention to MacDougall, Colegrove, and Wood?

If it is true that Anderson $v$. Jordan cannot be looked upon as a case disposed of on the ground of existence of an independent state ground of decision, what is its significance in the line of appor-

120 Baker v. Carr, 369 U.S. at 235.

121343 U.S. 393 (1952). See also Dixon v. Duffy, 342 U.S. 33 (1951).

122 See Appellant's Brief Opposing Motion To Dismiss or Affirm, p. 6, Anderson v. Jordan, 343 U.S. 912 (1952).

123 Dixon v. Duffy, 344 U.S. 143 (1952). 
tionment cases? The Supreme Court could have disposed of it on the ground that the matters sought to be litigated were outside the subject-matter jurisdiction of the Court. As we have seen before, this ground is untenable, and in any event if the Court thought the matter outside its jurisdiction it would hardly call attention to MacDougall. It could not have disposed of it upon the ground that as a matter of discretion federal courts will not exercise their equity powers in such cases, for Anderson was an appeal from a state court. Unless it depended upon the certificate controversy, then, the only way to explain Anderson is that it comes within the doctrine of MacDougall v. Green-that the Constitution does not require equal apportionment of electoral strength among the territorial subdivisions of the state. In Anderson, there was no reason assigned for the dismissal of the appeal. It was simply noted that the motion to dismiss was granted and the appeal dismissed. The motion to dismiss was based upon three points. The first was independent state ground; the second, want of jurisdiction; and the third, want of a substantiality of the federal question because the issue was "political."

Between Anderson v. Jordan and the next of the apportionment cases, a period of four years elapsed during which there were three changes in the Court's personnel. Mr. Chief Justice Warren replaced Mr. Chief Justice Vinson, Mr. Justice Harlan replaced Mr. Justice Jackson, and Mr. Justice Brennan replaced Mr. Justice Minton. In 1956, the Court had before it two apportionment cases. The first of these was Kidd v. McCanless, ${ }^{124}$ on appeal from a decision of the Tennessee Supreme Court refusing to invalidate the same Tennessee apportionment act which was later involved in Baker v. Carr. The state supreme court had held that it would not declare the act unconstitutional because under the Tennessee law of de facto officers, there could be no de facto officer after a judicial declaration that he did not hold his office de jure. ${ }^{125}$ Because of this, said the Court, were it to declare the act unconstitutional there would be no de jure legislature and no de facto legislature, even for the purposes of enacting another apportionment act, and the state would be left in chaos. In the United States Supreme Court the appeal was dismissed in a per curiam opinion which read: "The motion to dismiss is granted and the appeal is dismissed. Colegrove v. Green ..., Anderson

124352 U.S. 920 (1956).

125 See Kidd v. McCanless, 200 Tenn. 273, 292 S.W.2d 40 (1956). 
v. Jordan . . .".126 Mr. Justice Brennan, in his Baker opinion, stated, "Of course this Court was there precluded by the adequate state ground, and in dismissing the appeal ... we cited Anderson ... as well as Colegrove."'127 The motion to dismiss was grounded upon the existence of an independent state ground, the absence of a substantial federal question on the merits, and the view that apportionment is a "political question." 128 Of course, the decision of the Tennessee Supreme Court did rest upon the state law of remedies, and necessarily had to, since there were alleged, in addition to the violations of the Constitution of the United States, several patent violations of the constitution of Tennessee, so that even had the court decided that there were no violations of federal requirements, to sustain the demurrer it would have had to come to the conclusion that it was powerless to correct the local abuses. It seems, then, that the proper disposition of the case would have been to dismiss the appeal because of want of a federal question, precisely the reason assigned to the holding by Mr. Justice Brennan. But why were Anderson v. Jordan ${ }^{129}$ and Colegrove $v$. Green $^{130}$ assigned as authority? Colegrove could have no possible relevance to this issue. Mr. Justice Brennan suggested that the clue could be found in the fact that "we cited Anderson ... as well as Colegrove," for Anderson he had previously characterized as having been decided on the basis of an independent state ground. But when we follow the good Justice's method of finding clues, we discover, as we have already seen, that in Anderson we were referred to MacDougall, Colegrove, and Wood. This may have been, as Mr. Justice Brennan suggested, an effort to characterize the case as one dealing with the existence of an independent state ground. If so, one can only say with Goethe, "Wenn ich die Meinung eines Andern anhören soll, so muss sie positiv ausgesprochen werden; Problematisches hab' ich in mir selbst genug." 131

Not only does this backtracking of citations suggested by Mr. Justice Brennan lead one to suppose that Kidd v. McCanless takes its place among the apportionment cases which have developed the so-called Colegrove doctrine, but forward tracking does so as

126 Kidd v. McCanless, 352 U.S. 920 (1956). (Citations omitted.)

127369 U.S. at 236.

128 Statement in Opposition to Statement of Jurisdiction and Motion To Dismiss, p. 1, Kidd v. McCanless, 352 U.S. 920 (1956).

120343 U.S. 912 (1952).

130328 U.S. 549 (1946).

131 "If $\mathrm{I}$ am to listen to the opinion of another, then it must be precisely enunciated; I have sufficient difficulties of my own." 
well. At the same term the Court disposed of the appeal in Radford $v$. Gary. ${ }^{132}$ Radford arose in a federal district court, not in the state court system. It was a suit seeking an order in the nature of mandamus, requiring the Governor of Oklahoma to convene the legislature of that state, requiring the legislature to reapportion, and, that failing, requiring the Supreme Court of Oklahoma to do it for them. In an opinion by Judge Murrah, the district court held that under the Colegrove doctrine the case posed only "state political issues" with which the federal courts should not interfere, citing South $v$. Peters, and concluding that the facts of the case could not be distinguished from those in the Colegrove and MacDougall cases. ${ }^{133}$ Before the district court, motion was made to dismiss the action because the court lacked jurisdiction over the subject matter, and because the complaint failed to state a claim against defendants upon which relief could be granted. ${ }^{134}$ On appeal, the appellees moved in the following terms: "Appellees in the above entitled case move to dismiss on the ground that the questions presented in appellant's 'jurisdictional statement' herein are so unsubstantial as to not need further argument" and called to the Court's attention the pleadings, the motion to dismiss below, the majority opinion below, and "the decisions of the state and federal courts including the decisions of the Supreme Court of Oklahoma and of this Court cited and followed in said opinion." 135 They filed no briefs and made no arguments. They simply rested. The answer to the motion was filed on February 11, 1957, and on February 25 the Supreme Court handed down its decision, affirming the district court and citing Kidd v. McCanless and Colegrove v. Green.

So Kidd v. McCanless, which Mr. Justice Brennan suggested should be recognized as having been dismissed because of the existence of an independent state ground, through the citation of Anderson $v$. Jordan in its dismissal, some two months later was cited as authority for affirming the decision of a federal district court which dismissed an attack on a state apportionment scheme flatly on the ground that the Colegrove and MacDougall cases could not be distinguished. Mr. Justice Brennan said that "problems of relief also controlled in Radford $v$. Gary ... a affirming the District Court's refusal to mandamus the Governor to call a ses-

132352 U.S. 991 (1957).

133 Radford v. Gary, 145 F. Supp. 541 (W.D. Okla. 1956).

134 See Brief for Appellees, Radford v. Gary, 352 U.S. 991 (1957).

135 Ibid. 
sion of the legislature, to mandamus the legislature then to apportion, and if they did not comply, to mandamus the State Supreme Court to do so."136 In a sense, no doubt, problems of relief are part of the substructure of the Colegrove doctrine, whether one considers the doctrine as jurisdictional, as definitive of the periphery of the protection afforded by the fourteenth amendment, or simply as an example of judicial restraint. As Mr. Justice Frankfurter put it, "courts ought not to enter this political.thicket."137 If, on the other hand, Mr. Justice Brennan suggested that problems of relief take the Radford case out of the general class of cases seeking to plunge the federal courts into the "political thicket," or that the district court dismissed because of special difficulties in giving relief in this particular case under its facts and pleadings, he was clearly wrong. The district court took the view that Colegrove and the other cases which proliferated the doctrine of judicial non-intervention precluded any relief, not that the relief requested was inappropriate, or in a proper case beyond the power of this district court.

The next of the apportionment cases was filed during the October 1957 term. By this time Mr. Justice Reed had retired and his place had been taken by Mr. Justice Whittaker. The case was Hartsfield v. Sloan. ${ }^{138}$ In Hartsfield, the plaintiffs sought once again to overturn the Neill Primary Act in Georgia. The suit was brought in a federal district court against election officials, seeking to restrain them from counting primary election ballots according to the county unit system. In view of the fact that this was exactly the same dispute which had been before the Supreme Court in Cook v. Fortson (Turman v. Duckworth), South v. Peters, and Cox v. Peters, Judge Sloan refused to convene a three-judge court to hear it again. In an unreported opinion he reviewed the Court's holdings in South, Colegrove v. Green, MacDougall, and Cox. "Upon a careful review of the authorities dealing with the question of subdivision of an election territory," he said, "the Court is of the opinion that the federal question sought to be raised here is unsubstantial for the reason that the previous decisions of the Supreme Court of the United States foreclose the subject and leave no room for inference that the question sought to be raised can be the subject of controversy." "139 Following the method approved

130369 U.S. at 236.

137 Colegrove v. Green, 328 U.S. 549, 556 (1946).

138357 U.S. 916 (1958).

130 Hartsfield v. Sloan, N.D. Ga. 1958 (unreported). 
in Ex parte Poresky, ${ }^{140}$ the plaintiffs sought permission to file a writ of mandamus in the Supreme Court to require Judge Sloan to convene a three-judge court to hear the controversy. The petition was denied per curiam without opinion. The Chief Justice and Justices Black, Brennan, and Douglas were of the opinion that a rule to show cause should issue. The same four Justices were of the opinion that probable jurisdiction should be noted, and it was. ${ }^{141}$

Mr. Justice Brennan said of Hartsfield $v$. Sloan that, as in Remmey v. Smith, ${ }^{142}$ "problems of timing were critical. ... [M]ovants urged the Court to advance consideration of their case, 'inasmuch as the mere lapse of time before this case can be reached in the normal course of ... business may defeat the cause, and inasmuch as the time problem is due to the inherent nature of the case. ..." "143 In the motion to advance, movants pointed out that they had brought the suit below as soon as the announcement had been made that there was to be a primary election at some date between then and the general election scheduled for November 1958. They had refrained from bringing it prior to that time because, since Georgia law did not require any primary to be held, they were afraid that a suit brought before the announcement that a primary election was to be held would have been subject to dismissal on the ground that it was prematurely brought. They pointed out that "despite the delay occasioned by this petition for mandamus the petitioner can still obtain effective relief if this Court grants the writ by the end of this term. The Georgia general election ballots need not be finally prepared until the last days of October 1958." I44 In appraising the likelihood that Mr. Justice Brennan was correct in his interpretation of the meaning of the majority decision to decline to compel a hearing in Hartsfield, it is of interest that, despite this time factor, all of the three Justices who signed the Brennan opinion in Baker $v$. Carr voted to issue a rule to show cause in the Hartsfield case. Of the Court which heard Baker, only Justices Clark, Harlan, and Frankfurter were members of the majority in Hartsfield. In the Frankfurter dissenting opinion in Baker, joined in by Mr. Justice Harlan, the

140290 U.S. 30 (1933). See also Robertson \& Kirkham, JuRisdiction of the Supreme Court of The UnITED STATES § 211 (2d ed. Wolfson \& Kurland 1951).

141 Hartsfield v. Sloan, 357 U.S. 916 (1958).

142342 U.S. 916 (1952).

143 Baker v. Carr, 369 U.S. at 235.

144 See Motion To Advance, p. 2, Hartsfield v. Sloan, 357 U.S. 916 (1958). 
case is cited as supporting the Colegrove doctrine, ${ }^{145}$ and in the Clark opinion the case is not mentioned by name but the opinion contains the following statement: "Finally, the Georgia countyunit-system cases, such as South $v$. Peters . . . reflect the viewpoint of MacDougall, i.e., to refrain from intervening where there is some rational policy behind the State's system."146

The next, and last, of the pre-Baker apportionment cases was Matthews $v$. Handley. ${ }^{147} \mathrm{It}$ involved an attack on the validity of the Indiana gross income tax statute on the ground that the act was adopted by a legislature elected under an unconstitutional apportionment statute. The form of the case shows the desperation of the franchise reformers. Having lost in equity, mandamus, and common-law action for damages, they were undoubtedly seeking to present a new wrinkle to the Court, probably not so much because they thought that their case could be distinguished from the many cases denying relief, as because they no doubt noted the facts that the Chief Justice and Justices Black, Brennan, and Douglas had voted to issue the rule to show cause in Hartsfield, and that between 1958 and $1961 \mathrm{Mr}$. Justice Stewart had replaced Mr. Justice Burton. Mr. Justice Burton's retirement left Mr. Justice Frankfurter the lone survivor of the original adherents to the latter's position in Colegrove v. Green. On the other hand, two of the original dissenters remained unconverted.

The district court dismissed the suit in Matthews, but, while it was not disposed to hold that the Colegrove doctrine was in any sense weakened, it provided the Court with a possible excuse for not strengthening it by holding that in any event the state law provided an adequate means for testing the validity of the tax as applied to the plaintiffs, including the constitutionality of the statute. On appeal, the judgment of the district court was affirmed in a per curiam decision without opinion and without citation of authority. Mr. Justice Brennan took the affirmance to mean that where there is an adequate state procedure for testing the validity of a state statute, the federal courts will not enjoin its operation. ${ }^{148}$

B. The Clark Opinion: Texans Shoot from the Hip

Mr. Justice Clark agreed with his brother Brennan that the issues raised in Baker were part of a subject matter over which the

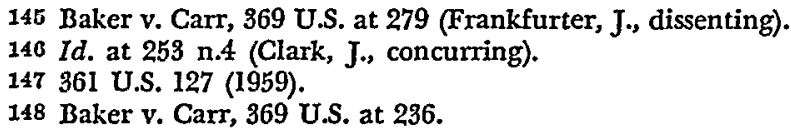


federal courts have jurisdiction, and that they were not non-justiciable "political questions." He also joined the majority in sending the case back for a decision on the merits. Left to himself to decide the case, he would have gone further and held for the plaintiffs on the merits. He was of the opinion that the majority in substance had done so, and he preferred to be straightforward about it. Where, as in Baker, judgments granting motions to dismiss are reversed on appeal, the normal procedure is to remand for trial so that the defendant can present any evidence he has, but, in cases in which the facts are not in dispute, there is precedent for final disposition of the cause by the appellate court. ${ }^{149}$ In the Baker case the facts were not in dispute. The case was not one of urgency, however. Tennesseeans had waited half a century for reapportionment and they could not be said to be mightily inconvenienced by the majority's insistence that defendants get an opportunity to present evidence before judgment is entered against them.

If Mr. Justice Clark's objection was to the majority's pretenses that it was not deciding the merits of the constitutional claim under the facts as admitted in the motion to dismiss, he was on sound ground. The case came up on admitted facts and the normal manner of deciding it would have been to rule one way or another on the question of whether the pleadings stated a claim on which relief could be granted..$^{150}$ The majority disposition of the case left it undecided whether a claim was stated, and remanded, presumably for a formal determination on that issue. Why such a remand was necessary or desirable escapes the writer completely. All it could accomplish would be to add to the Court's fund of lower court opinions on the merits of an argument already before it fifteen times. It is possible, but improbable, that an opinion from one more three-judge court would add any new insight.

Since he would have decided the merits, it was necessary for Mr. Justice Clark to distinguish the cases which Mr. Justice Brennan had disposed of in his opinion. Since with some differences in language most of them were given the same treatment, it is unnecessary to go down the list, but the differences are worthy of mention. Tedesco $v$. Board of Supervisors ${ }^{151}$ and Colegrove $v$. Green $^{152}$ were put aside because in those cases, said Mr. Justice

149 See 5 Moore, Federal. Practice q 41.13(2) (2d ed. 1951).

1505 id. ff 41.13(1). See also FEd. R. Civ. P. 41(b).

151339 U.S. 940 (1950).

152328 U.S. 549 (1946). 
Clark, the appellants did not argue the equal protection clause. ${ }^{153}$ In the case of Tedesco, this may have been technically correct. At least the appellants did not mention that clause by that name. The claim was made under the due process clause and under the fourteenth amendment in general, so to speak. But the appellants' claim that the fourteenth amendment prohibited unequal apportionment of the city was spoken of by the appellees as an equal protection claim, ${ }^{154}$ and the appellants insisted in their summary of points that they were relying upon all of the first section of the fourteenth amendment. ${ }^{155}$ If it can be said that the appellants did not argue the equal protection clause, the truth of the assertion depends upon their failure to refer to the subject clause by its popular name.

As applied to Colegrove v. Green, such a statement is palpably incorrect. In the complaint, assignments of error, the appellants' brief, and the amicus brief filed by the Better Government Association, reliance upon the equal protection clause fairly leaps at the reader. ${ }^{156}$ It is true that in the Frankfurter opinion the clause was not mentioned by name, the constitutional claims being lumped together as made under "various provisions of the United States Constitution." ${ }^{157}$ But in Mr. Justice Black's dissenting opinion the equal protection claim was recited. Indeed, Mr. Justice Black's disagreement with the ultimate disposition of the case depended upon his belief that appellants had demonstrated a denial of equal protection of the laws. ${ }^{158}$

153 Baker v. Carr, 369 U.S. at 252 (Clark, J., concurring).

154 See Statement Opposing Jurisdiction and Motion To Dismiss or Affirm, p. 2, Tedesco v. Board of Supervisors, 339 U.S. 940 (1950): "He also would predicate a denial of equal protection of the laws on the circumstance that there is a disparity of electors in the electoral districts."

165 See Brief for Appellant Opposing Motion of Appellees To Dismiss or Affirm, p. 4, Tedesco v. Board of Supervisors, 339 U.S. 940 (1950): "That appellant relies not only upon the first clause of the second sentence of Section 1 of the Fourteenth Amendment, but upon the entire section."

150 See Transcript of Record, Assignment of Errors, Colegrove v. Green, 328 U.S. 549 (1946): "The District Court erred in failing to hold that the . . . Act violates the rights of the plaintiffs under the 'privileges and immunities' clause, the 'due process' clause and the 'equal protection of the laws' clause of the Fourteenth Amendment to the Constitution of the United States." See Brief and Arguments for Appellants, p. 62, under heading: "The Illinois . . . Act Also Particularly Denies to the Appellants the Equal Protection of the Laws in Violation of the Fourteenth Amendment." See also Brief for the Better Government Association as Amicus Curiae, p. 36: "The Illinois Redistricting Act of 1901 which defendants seek to enforce creates such gross inequalities in the Congressional districts as to deny to plaintiffs the equal protection of the laws guaranteed by Section 1 of the Fourteenth Amendment."

157 See Colegrove v. Green, 328 U.S. 549,550 (1946).

158 Id. at 568: "The complaint attacked the 1901 Apportionment Act as unconstitutional and alleged facts indicating that the Act denied appellants the full right to vote and the equal protection of the laws." 
Mr. Justice Clark's mistake in this connection may be explained by his adherence to the view of Wood v. Broom ${ }^{150}$ espoused by the signers of the Brennan opinion. In putting aside the Frankfurter language on "political questions" as no more than an alternative ground, he appended a footnote in which he said: "The opinion stated ... that the Court 'could also dispose of this case on the authority of Wood v. Broom....' Wood v. Broom involved only the interpretation of a congressional reapportionment Act."100 The reasoning seems to run from the assumption that Wood was a case not involving constitutional issues to the conclusion that Mr. Justice Frankfurter's willingness to dispose of Colegrove $v$. Green on the authority of Wood demonstrates that Colegrove, too, involved no constitutional claim. There are two difficulties with this line of reasoning. First, in each case the claim rested both under the statute and under the equal protection clause. It is all very well to say that a policy against decision of constitutional issues unadorned by discussion leads the Court to treat as open the questions which have been disposed of in this way. It does not follow that the case did not involve a constitutional issue. Where in a second case the judge deems himself bound by the first, there are two possible inferences. The first is that the case did not involve a constitutional claim; the second, that the court in the second case took the first case to foreclose the constitutional as well as the statutory issue. ${ }^{161}$ Clearly the district court read the Wood case as ruling out both the statutory and constitutional claims in Colegrove v. Green, for it said: "In the absence of this decision we would assume that such a requirement [of substantial equality of population in congressional districts] arose necessarily from the Constitution." 162 When Mr. Justice Frankfurter said in Colegrove that "the District Court was clearly right in deeming itself bound by Wood $v$. Broom, . . . and we could also dispose of this case on the authority of Wood v. Broom,"163 the statement was to be read against the statement by the lower court that it took Wood as precluding judicial vindication of a right the court would

159 See text supra at 715.

160 Baker v. Carr, 369 U.S. at 252 n.1.

161 The latter was clearly the way Wood $v$. Broom was read by the Illinois Supreme Court in Daly v. County of Madison, 378 IIl. 357, 364, 38 N.E.2d 160, 164 (1941): "That there is nothing in the fourteenth amendment which would render invalid congressional districts created by State legislation, on the ground that they are unequal in population, was settled by the decision of the Supreme Court of the United States in Wood v. Broom . . . "

16264 F. Supp. 632, 634 (N.D. Ill. 1946).

163 Colegrove v. Green, 328 U.S. 549, 551 (1946). 
have thought was constitutionally protected. Second, regardless of the inferences which might otherwise be drawn from the willingness of Mr. Justice Frankfurter to dispose of the Colegrove case on the authority of Wood $v$. Broom, we know as a fact that in Colegrove the claim under the equal protection clause was urged upon the Court, and that the question of whether these claims were foreclosed by Wood $v$. Broom was argued by counsel. ${ }^{164}$

The peculiar feature of this slip on the part of Mr. Justice Clark was the fact that the absence of an equal protection claim in Colegrove v. Green was wholly unnecessary to his willingness to set this case aside. He had already pointed out that the Frankfurter view was not the prevailing one. Having hit his target the first time, he merely weakened his total argument by loosing this second hail of hip shots.

Though willing to go further than his brethren in the disposition of the Baker case itself, the ground on which $\mathrm{Mr}$. Justice Clark would have put the result is a narrow one. He said that he relied on MacDougall $v$. Green. ${ }^{165}$ That disposed of the arguments on jurisdiction and justiciability. But it is wholly inconsistent with the theory that the equal protection clause prohibits a state from apportioning political influence among its geographic subdivisions with an eye to density as well as number of inhabitants. And Mr. Justice Clark did not question this principle. But the present Tennessee apportionment struck him as outlandish enough to be classified as wholly arbitrary, and, as such, in violation of the Constitution. He noted that not only was there a great difference between large counties and small counties, but also among large counties and among small counties. In short, there was no rational pattern at all. He distinguished South $v$. Peters, in which he had joined the majority, as grounded upon the existence of a rational plan-six units for the largest counties, four for middle-sized counties, and two for small counties. It will be remembered that in South the plaintiffs pleaded that the difference in the representation ratio as between the largest county and the smallest was one to one hundred and twenty-two. ${ }^{166}$ In MacDougall it was stated by the Court that the fifty-three smallest Illinois counties, with thirteen percent of the population, held an absolute veto over the creation of new parties by people in the remaining fifty

164 See Brief and Argument for Appellants, p. 65, Colegrove v. Green, 328 U.S. 549 (1946). See also Brief by Better Government Association, p. 30.

165335 U.S. 281 (1948).

100 See note 66 supra. 
counties, with eighty-seven percent of the population. ${ }^{107}$ Nor was the veto mutual. The thirteen percent could force a name on the ballot with no support among the eighty-seven percent. To Mr. Justice Clark, then, the line between constitutionality and unconstitutionality is not a mathematical one, but one of reasonable classification.

In its practical application the Clark view may have special, if not exclusive relevance to the case, like Baker, in which the alleged discriminations are the product of passage of time and shifts in population. In cases of conscious design apparently the usual presumptions of constitutionality make courts chary of saying that a given pattern has no logic to support it, for, as Judge Janvier observed in Tedesco v. Board of Supervisors, there may be groups, social and otherwise, ${ }^{168}$ which the legislature thought should be represented. Whatever rational base the Court might think of as a possibility, it knows as a fact that the discrepancies in representation ratio as between Tennessee counties was not a matter of conscious design at all. It knows this because in 1901 the legislature took as its criterion for distribution the straight population requirement of the Tennessee constitution and did a middling fair job of apportionment.

The trouble with this view is that if the legislature may design a bracket structure which will afford the populous counties no more representation than they now enjoy, or under the South case less, the Clark decision in Baker avails them nothing. It would force elimination of the odd and crazy differences among smaller counties, but the residents of these counties have made no complaint, and it seems strange to permit residents of Memphis, Nashville, Chattanooga, and Knoxville to raise the question of whether residents of Washington County are afforded greater representation than those of Unicoi County if their own representation is within constitutionally permissible ranges. The net effect is to require that rural bias, to be constitutional, must be advertent, certainly a reverse twist on the role of intention in equal protection cases.

\section{G. The Douglas Opinion: Substantial Equality}

Mr. Justice Douglas, like his brother Clark, would have decided the case on the merits. He would have done so, however,

167 MacDougall v. Green, 335 U.S. 281, 283 (1948).

168 See Tedesco v. Board of Supervisors of Elections for Parish of Orleans, 43 So. 2d 514, 519 (La. Ct. App. 1949). 
in the normal way, reversing the district court determination that the plaintiffs did not state a claim on which relief can be granted and remanding for a trial of the facts. ${ }^{168}$ Since his views on the merits of the claim have been well known for sixteen years, ${ }^{170}$ his opinion came as no surprise. This time, however, he took occasion to serve notice that his conception of the role of courts in protecting the people against unfair operation of the political process does not stop with apportionment of representatives in the legislature. Conceding that there is a narrow range of political issues which are beyond judicial competence, he would confine them to cases in which discretionary duties are vested directly upon executive officers by the Constitution, ${ }^{171}$ and cases in which particular functions have been assigned "wholly and indivisibly" to another department. ${ }^{172} \mathrm{He}$ indicated that his views led him to disagree with the decisions in Luther $v$. Borden ${ }^{173}$ and Georgia $v$. Stanton. ${ }^{174}$

On the subject of the issues posed in Baker, Mr. Justice Douglas stated three limitations on the power of the states to apportion representation. First, the fifteenth amendment prevents discrimination based upon race. Second, the nineteenth amendment prevents discrimination based upon sex. Third, the equal protection clause of the fourteenth amendment prohibits other "invidious discriminations." This left him with the necessity of showing that there had been alleged in Baker a discrimination which is "invidious."

"I agree with my Brother Clark that if the allegations in the complaint can be sustained a case for relief is established. We are told that a single vote in Moore County, Tennessee, is worth 19 votes in Hamilton County, that one vote in Stewart or in Chester County is worth nearly eight times a single vote in Shelby or Knox County. The opportunity to prove that an 'invidious discrimination' exists should therefore be given the appellants."175

160369 U.S. at 241 (Douglas, J., concurring).

170 See, e.g., Colegrove v. Green, 328 U.S. 549, 566 (1946); MacDougall v. Green, 335 U.S. 281, 287 (1948); South v. Peters, 339 U.S. 276, 277 (1950); Anderson v. Jordan, 343 U.S. 912 (1952); Hartsfield v. Sloan, 357 U.S. 916 (1958); Gomillion v. Lightfoot, 364 U.S. 339,348 (1960).

171 Kentucky v. Dennison, 65 U.S. (24 How.) 66 (1860). See also 369 U.S. at 245.

172 See, e.g., Oetjen v. Central Leather Co., 246 U.S. 297 (1918). See also 369 U.S. at 246.

17348 U.S. (7 How.) I (1849); see 369 U.S. at 242 \& n.2.

17473 U.S. (6 Wall.) 50 (1867); see 369 U.S. at $246 \&$ n.3.

175369 U.S. at 245. 
This observation leaves unspoken the criteria of invidiousness. In one breath it seems to say that having shown the order of difference to be nineteen to one and eight to one, a claim has been made on which relief can be granted. In the next, that the order of difference entitles the plaintiffs to no more than an opportunity to submit proof that the discrimination is an invidious one. As Mr. Justice Frankfurter pointed out in his dissent, Baker was not a case like Gomillion v. Lightfoot, ${ }^{176}$ in which the geographical classification was alleged to screen a difference of treatment made along other and prohibited lines. Since Mr. Justice Douglas conceded that there "is room for weighting,"177 the "invidiousness" here must lie in the order of difference, rather than in the basis of the classification; unless, perhaps, he was suggesting, as Mr. Justice Glark did, that the question was one of utter lack of rational pattern. Apparently it was the former. In a footnote it was stated that "the District Court need not undertake a complete reapportionment. It might possibly achieve the goal of substantial equality merely by directing respondent to eliminate the egregious injustices." 178 This suggests that Mr. Justice Douglas did view the problem as one of order of difference. Absolute equality is not required, but substantial equality is.

Taking this view of "invidiousness," it is surprising that Mr. Justice Douglas did not join his brother Clark in voting to dispose of the case then and there, for certainly the order of the differences was not in dispute. Within Mr. Justice Clark's formulation, it is conceivable that the defendants could suggest some possible rational basis or give some explanation which would convince a court that the system was not completely chaotic, for, on the allegations alone, Mr. Justice Harlan was so convinced. If substantial equality is required, however, substantial equality there is not. What the plaintiffs are required to prove that is not a matter of record, Mr. Justice Douglas left unclear.

Since he has frequently expressed his disagreement with the Colegrove line of cases, it comes as no surprise that he did not trouble himself with coining his own methods of disposing of them. He simply noted that the only impediment to relief in these cases has been the opinion in Colegrove, "and the cases it spawned," and that this impediment had been removed by what the Court had said about them. 


\section{The Stewart Opinion}

"That is not it at all,

"That isn't what I meant at all."

T. S. Eliot

Mr. Justice Clark suggested that the reader might emerge from the Court's six opinions suffering from mental blindness. ${ }^{179}$ His brother Stewart attempted to avoid this result by simplifying and interpreting the Court's decision. It holds, said Mr. Justice Stewart, besides that appellants have standing, two things, and only two: first, that the issues posed in Baker are within the subject-matter jurisdiction of the district courts, and second, that they do not pose non-justiciable "political questions."180

He scored Mr. Justice Douglas for suggesting that the Court was holding that there must be substantial equality of voting strength as between urban and rural areas, citing MacDougall as holding to the contrary. He spoke of Mr. Justice Clark's showing of the irrationality of the Tennessee system and Mr. Justice Harlan's defense of it as not to the point. "The merits of this case are not before us now," he continued, "the defendants have not yet had an opportunity to be heard in defense of the State's system of apportionment; indeed, they have not yet even filed an answer to the complaint. As in other cases, the proper place for the trial is in the trial court, not here."181

This is a round-sounding phrase, but Baker $v$. Carr came to the Court on appeal from the judgment of the district court granting a motion to dismiss. Such a motion admits all facts properly pleaded and contends that, even so, the complaint does not state a claim on which relief can be granted. Whether those facts can be proved is of course not before the appellate court. The merits of the constitutional claim are. ${ }^{182}$ It was only by narrowly construing the judgment of the district court that the majority was able to say with any plausibility at all that the merits were not before it. ${ }^{183}$ The district court construed the Colegrove lines of cases as holding that, under the facts alleged, no claim had been stated on which relief could be granted. ${ }^{184}$ It was reversed, and its judg-

178369 U.S. at 25 I (Clark, J., concurring).

$180 \mathrm{Id}$. at 265 (Stewart, J., concurring).

181 Id. at 266.

182 See 5 MOore, op. cit. supra note 149.

183 See 369 U.S. at 195-98.

184 See Baker v. Carr, 179 F. Supp. at 826. 
ment vacated. ${ }^{185}$ Presumably, however, the merits of the constitutional question could then be raised by another motion to dismiss, rather than by a trial, or even an answer to the complaint, so it does not answer Justices Clark and Douglas, and the dissenters, to say the merits were not before the Court because a trial had not been held. Given the posture of the case, a trial was not necessary, and the rules provide such procedure for the express purpose of avoiding unnecessary trials.

\section{E. The Majority: You Can't Tell the Players Without a Scorecard}

It remains to piece together the view of the Court's present personnel on the central question-the effect of the equal protection clause on the power of the state to distribute representation among its geographical subdivisions.

The one thing that is clear is that the Court was of the opinion that the question is within the subject-matter jurisdiction of the district court, and is not a non-justiciable "political question."188 This holding is supported by six members, a comfortable majority, and unaffected by intervening changes in the make-up of the Court.

On the merits of the particular claim in the Baker case, the situation is not quite clear. The Brennan opinion purported not to decide the issue, but then proceeded to say in a footnote: "Since we hold that the appellants have-if it develops at trial that the facts support the allegations-a cognizable federal constitutional cause of action. ..."187 Further, we know the views of Mr. Justice Black because of his dissenting opinion in Colegrove v. Green and because he joined the dissent in MacDougall v. Green and in South v. Peters. It is probable, therefore, that a majority of fiveJustices Black, Brennan, Clark, Douglas, and the Chief Justicewould hold for the appellants on the merits, Mr. Justice Harlan dissenting and Justices Goldberg, Stewart, and White yet to be heard from.

On the constitutional requirement of substantial equality of representation, the position of Mr. Justice Douglas is clear, and, from previous dissenting opinions, we know that his view is shared by Mr. Justice Black. On the other hand, the suggestion that rural bias is unconstitutional as such was expressly rejected by Justices

\footnotetext{
185369 U.S. 186 (1962).

186 But see text infra at 790.

187369 U.S. at 195 n.15.
} 
Clark and Stewart. Even if the Brennan opinion can be taken as placing its adherents on the side of Justices Clark and Douglas on the merits of the particular claim, it gave no hint at all as to whether the reason lies in the general irrationality of the scheme (a la Clark), or is grounded in the belief that rural bias is proscribed (a la Douglas). All that can be said is that at least two, and perhaps four, of the members of the Court share this position, and that three-Justices Clark, Harlan, and Stewart-do not. This leaves the issue in the hands of the newly-appointed Justices Goldberg and White, who could determine a majority either way.

So after thirty years of litigation, twelve years of silence and 50,000 words, the application of the equal protection clause to problems of apportionment is still in great doubt, in extent if not in fact.

\section{F. The Frankfurter Opinion: A Parting Thrust at the New Court Militant}

The Colegrove doctrine was not buried without accusation that it was the victim of foul play. Mr. Justice Clark referred to the Frankfurter opinion as "go[ing] through so much and conclud[ing] with so little,"188 a clever piece of persiflage, perhaps, but hardly apt. The conclusions reached by Mr. Justice Frankfurter were plain enough. They were three in number. The first had to do with judicial precedent. Though he spoke of the appellants when he said, "It would only darken counsel to discuss the relevance and significance of each of these assertedly distinguishing factors here and in the context of this entire line of cases," 189 a reader having gone through what Justices Brennan and Clark had to say about these cases can scarcely resist the conclusion that their brother Frankfurter's barb had struck home. For certainly the conclusion that a bald claim of difference in representation ratio as between geographical subdivisions is not such a claim as will support equitable relief fairly screams from the apportionment cases decided by the Court in the past thirty years. The attempts to distinguish all of them, resting as they do upon tissue-thin distinctions, and in some cases upon distinctions which are in fact simply not present, are little better than a shell game. Assuming that there is any such constitutional right, the concession that for thirty years the Court has refused to enforce it on the divers grounds sug-

188369 U.S. at 251.

$180 \mathrm{Id}$. at 280 . 
gested by Mr. Justice Brennan is enough to shake the confidence of the most staunch of the Court's admirers. That the majority opinion, if it be read from the footnote rather than the text, ${ }^{100}$ flies in the teeth of the precedents, is so plain that it is not even arguable. There have been variations in parlance, to be sure, but as Mr. Justice Frankfurter pointed out:

"If the weight and momentum of an unvarying course of carefully considered decisions are to be respected, appellants' claims are foreclosed not only by precedents governing the exact facts of the present case but are themselves supported by authority the more persuasive in that it gives effect to the Colegrove principle in distinctly varying circumstances in which state arrangements allocating relative degrees of political influence among geographic groups of voters were challenged under the Fourteenth Amendment."191

The second conclusion dealt with the application of the "political question" doctrine to the facts of the Baker case. Like the majority, Mr. Justice Frankfurter had some cases to distinguish, for it could not be gainsaid that in Smiley v. Holm, ${ }^{192}$ Koenig $v$. Flynn, ${ }^{193}$ Carroll v. Becker, ${ }^{194}$ McPherson v. Blacker, ${ }^{195}$ and MacDougall $v$. Green, ${ }^{106}$ the Court did adjudicate matters dealing with apportionment, and in the cases dealing with alleged Negro disfranchisement the Court had not hesitated to interfere to protect a right to equal enfranchisement. In one of them, Gomillion $v$. Lightfoot, ${ }^{197}$ it had gone as far as in effect to change the boundaries of a city.

Smiley, Koenig, and Carroll were ail distinguished as cases in which the Court freed the states from supposed limitations under the Constitution. In such cases, suggested Mr. Justice Frankfurter, there were no problems "demanding the accommodation of conflicting interests for which no readily accessible judicial standards could be found." 198 In McPherson v. Blacker, too, though the Court treated as justiciable the question of whether a state could

190 As, indeed, it undoubtedly can, since the decision in W.M.C.A., Inc. v. Simon, 370 U.S. 190 (1962); see discussion of the Simon case infra at 762-64.

191369 U.S. at 280 (Frankfurter, J., dissenting).

192285 U.S. 355 (1932).

193285 U.S. 375 (1932).

194285 U.S. 380 (1932).

195146 U.S. 1 (1892).

196335 U.S. 281 (1948).

197364 U.S. 339 (1960).

198369 U.S. at 285. 
provide for the election of its presidential electors from districts, it held that the method of choosing such electors was left in the absolute discretion of the state. "To read with literalness the abstracted jurisdictional discussion in the $M c$ Pherson opinion," said Mr. Justice Frankfurter, "reveals the danger of conceptions of 'justiciability' derived from talk and not from the effective decision in a case."199 The Negro disfranchisement cases were distinguished as resting upon a clear constitutional imperative under the fifteenth amendment, and "no less" under the equal protection clause of the fourteenth. ${ }^{200}$

This writer is on record as suggesting that framing the issues posed in the apportionment cases in terms of what sorts of controversies are "justiciable" and what are not only serves to confuse them. ${ }^{201}$ In Gomillion v. Lightfoot, for instance, Mr. Justice Frankfurter said that the violation of the fifteenth amendment "[lifts] this controversy out of the so-called 'political' arena into the conventional sphere of constitutional litigation." ${ }^{02}$ Conceding that the problem may be thus described without changing the outcome, it is suggested that consideration in these terms ultimately requires a determination on the merits of the existence or non-existence of the constitutional right asserted in the claim. If so, is it not better to proceed directly to that problem? In the Gomillion case, would it not have been more precise to say that in the apportionment cases the plaintiffs asserted a right to equality of representation by population, a right not vouchsafed to them by the fourteenth amendment, while in Gomillion it was alleged that the statute in question infringed the plaintiffs' right not to be treated differently because of their race, a right which is vouchsafed to them by the fifteenth? As Mr. Justice Harlan said in his dissenting opinion in Baker, an opinion in which Mr. Justice Frankfurter joined, one asks the same questions to determine the existence of the right under the fourteenth amendment that would be asked in determining the existence of a "political question" said to be non-justiciable. ${ }^{203}$

Nor is the language of constitutional substance absent from any of the Frankfurter opinions. In Gomillion, for example, he

108 Id. at 285.

200 Id. at 285-86.

201 See Lucas, Dragon in the Thicket: A Perusal of Gomillion v. Lightfoot, 1961 SUPREMe Court Rev. 194, 223.

202364 U.S. 339, 346-47 (1960).

203369 U.S. at 337 (Harlan, J., dissenting). 
distinguished the line of cases, such as Hunter $v$. City of Pittsburgh, ${ }^{204}$ in which the Court had refused to interfere with the state's free exercise of the power to create political subdivisions and define their boundaries and powers, by pointing out that in these cases the infringement complained of was grounded on an asserted right to equality of taxation and a right to continued exercise of delegated powers, neither of which is guaranteed under the Constitution. And in his opinion in Colegrove v. Green, he began by saying that the case could be disposed of under Wood $v$. Broom. In MacDougall $v$. Green, he joined in an opinion which held squarely that the fourteenth amendment did not prohibit allocation of political influence disproportionate to population.

This brings us to the third conclusion. Mr. Justice Frankfurter determined that the claim in the Baker case did not charge a violation of the equal protection clause. The essence of the claim, he stated, was the assertion that "the equality which [the equal protection clause] guarantees comports, if not the assurance of equal weight to every voter's vote, at least the basic conception that representation ought to be proportionate to population, a standard by reference to which the reasonableness of apportionment plans may be judged." To find such a requirement legally enforceable in "the broad and unspecific guarantee of equal protection is to rewrite the Constitution." 205 The trouble with appellants' assertion that the principle of representation proportioned to the geographic spread of population is "the basic principle of representative government," said Mr. Justice Frankfurter, "is, to put it bluntly, [that it is] not true." 200

Is there a difference, then, between saying that, as a general proposition matters of politics are not justiciable, but, when the rights asserted are guaranteed by other provisions of the Constitution, the fact that they are so guaranteed lifts the controversy out of the "political arena" and "into the conventional sphere of constitutional litigation," on the one hand, and on the other saying simply that the fourteenth amendment to the Constitution does not establish such a right? Both approaches leave the result to depend upon the existence of the right under the "other provisions of the Constitution." But when we talk about non-justiciability, we pretend not to have considered whether or not the right 
exists, when in fact we have. The different treatment accorded Pacific States Tel. \& Tel. Co. v. Oregon ${ }^{207}$ in the Brennan and Frankfurter opinions illustrates this point. In this case attack was made on the constitutionality of an Oregon license tax statute on the ground that it was enacted by initiative act, in violation, it was alleged, of the "republican form of government" clause, the due process clause, and the equal protection clause. The Court held that the matter was not justiciable under the guaranty clause and that allegations of violation of the fourteenth amendment did not add anything to the complaint. Mr. Justice Brennan said of the Pacific States Tel. \& Tel. Co. case that the due process and equal protection claims were held non-justiciable not because they were joined with a guaranty clause claim, "but because the Court believed that they were invoked merely in verbal aid of the resolution of issues which, in its view, entailed political questions. ... We conclude then that the nonjusticiability of claims resting on the Guaranty Clause which arises from their embodiment of questions that were thought 'political,' can have no bearing upon the justiciability of the equal protection claim presented in this case. ..."208 In the Frankfurter opinion, the same case was used to show that one cannot lift an attack upon the general organization of a state into a justiciable question by attaching an equal protection label to the claim. ${ }^{209}$

The reason that the Baker case fell outside the rationale of Pacific States Tel. \& Tel. Co., to Mr. Justice Brennan, was that he had already decided that the claim stated a case of individual deprivation under the equal protection clause, and that clause was not invoked merely as a verbal aid to a claim which alleged only the general unrepublican character of the state's government. To Mr. Justice Frankfurter, it fell within the case precedent because there was charged only "that the frame of government is askew";210 in short, because there was stated no individual deprivation cognizable under the equal protection clause. The equal protection claim became, then, merely an effort to pull up a guaranty clause claim by the bootstraps.

Mr. Justice Harlan suggested that the majority was confused by the framing of the issues in terms of justiciability, rather than in terms of what states a cause of action under the equal protec-

207223 U.S. 118 (1912).

208 Baker v. Carr, 369 U.S. at 228.

209 Id. at 290-92.

$210 \mathrm{Id}$. at 299. 
tion clause. ${ }^{211}$ The writer suggests that the majority may not be so much confused as willing to employ confusion inherent in this manner of speaking as a wedge for introduction of their own views of the merits the unadorned statement of which would be even more flatly opposed to the precedents.

\section{G. The Harlan Opinion: A Straightforward Answer to a Straightforward Question}

In his dissenting opinion, joined in by Mr. Justice Frankfurter, Mr. Justice Harlan said, "once one cuts through the thicket of discussion devoted to 'jurisdiction,' 'standing,' 'justiciability,' and 'political question,' there emerges a straightforward issue which, in my view, is determinative of this case. Does the complaint disclose a violation of a federal constitutional right, in other words, a claim over which a United States District Court would have jurisdiction. . . ?"212 He went on to say that he found nothing in the equal protection clause or elsewhere in the federal constitution which expressly or impliedly supports the view that state legislatures need be structured so as to reflect approximate equality of the voice of every voter, and thought the matter settled in MacDougall v. Green ${ }^{213}$ and reaffirmed in South v. Peters. ${ }^{214}$ If no such requirement can be read from the Constitution, the only other contention present in the claim is that the Tennessee scheme of apportionment is so whimsical and arbitrary as to violate the equal protection clause without reference to a requirement that apportionment be substantially equal.

Rationality of apportionment schemes, said Mr. Justice Harlan, cannot be determined by the application of arithmetic symbols, there being many factors other than population which might have influenced the legislature in its allocation of seats. Without regard to these factors, he was able to see a pattern in the Tennessee system, with what he referred to as "slight disparities between rural areas."

Legislative inaction Mr. Justice Harlan took to be as surely an exercise of legislative power as action. ${ }^{215}$ In letting the apportionment stay the way it was, the legislative policy was plainly to retain the rural representation, regardless of shifts in population.

211 Id. at 331.

212 Id. at 330-31 (Harlan, J., dissenting).

213335 U.S. 281 (1948).

214339 U.S. 276 (1950).

215369 U.S. at 336. 
Apparently referring to Mr. Justice Clark, he suggested that at least some of the majority conceded that rural bias would not of itself be unconstitutional. ${ }^{216} \mathrm{He}$ did not see that it was more so by virtue of the fact that the legislature of Tennessee had accomplished it by refusing to reapportion.

\section{Scholle v. Hare}

Scholle v. Hare, ${ }^{217}$ decided one month after Baker v. Carr, involved an appeal from a decision of the Supreme Court of Michigan dismissing an original action of mandamus brought to challenge the validity of a 1952 amendment to the Michigan constitution fixing permanent state senate districts. ${ }^{218}$ It was contended that the amendment, adopted at the general election of 1952 by a margin of 300,000 votes, violated the due process and equal protection clauses of the fourteenth amendment, in that it established an unreasonable and arbitrary distribution of state senators among senate districts established in the amendment itself.

Prior to the adoption of the 1952 amendment, the state constitution required senate representation according to population. ${ }^{210}$ Under its provisions the Michigan legislature had divided the state into thirty-two senate districts, each electing one senator. There had not been a reapportionment of the legislature in Michigan since 1925, then relying on the 1920 census. As in Illinois and in Tennessee, there had been significant shifts in population since that time, and 1950 found a variation in population between the largest and smallest districts of 8.9 to 1 . The plaintiff lived in the twelfth district which was the second largest, with 8.7 times the population of the smallest. The effect of the 1952 amendment was to increase the total number of senators elected to thirty-four,

$216 I d$. at 340 .

217369 U.S. 429 (1962).

218 Mich. CoNst. art V, \& 2, as amended (1952).

210 Mrch. Consr. art. V, $\& 2$ (1908). This provision read: "The Senate shall consist of thirty-two members. Senators shall be elected for two years and by single districts. Such districts shall be numbered from one to thirty-two, inclusive, each of which shall choose one senator. No county shall be divided in the formation of senatorial districts, unless such county shall be equitably entitled to two or more senators." In $\S 3$ of the same article, provision was made for districts in the house of representatives, "which shall contain as nearly as may be an equal number of inhabitants ...." On the basis of the language employed, it could be argued that the Michigan constitution did not require apportionment of senators according to population. The Supreme Court of Michigan read the last sentence of $\S 2$ as requiring such apportionment. See Williams v. Secretary of State, 145 Mich. 447, 108 N.W. 749 (1906), under a former provision, and Ops. ATT'Y GEN. MICH. 246, 248 (1923-1924); id. at 81 (1925-1926). 
to remove the constitutional requirement of decennial apportionment, and to make two small changes in the districts as they existed under the act of 1925. Lapeer and St. Clair counties were separated from the eleventh district (formerly Macomb, Lapeer, and St. Clair) and made into a separate district (the thirty-fourth), and Washtenaw County was severed from the twelfth (Oakland and Washtenaw), and became the thirty-third.

During the period between 1925 and the filing of the action in Scholle v. Hare, the Michigan legislature had twice reapportioned the seats in the lower house. ${ }^{220}$ Under the present apportionment of the lower house, Oakland County, the county in which the plaintiff resided, is given six seats of the 110 provided for in the reapportionment act of 1953. This apportionment presumably rests on the census of 1950, according to which Oakland had 396,001 inhabitants. On a population basis, Oakland would be entitled to six and a major fraction representatives. It can be said, then, that as far as Oakland County goes, it was given roughly proportional representation in the lower house. The problem in the Scholle case was therefore different from the one posed in Baker $v$. Carr, where the legislature had permitted the representation ratio in both houses to reach a high point in rural bias. The obvious bargain drawn in Michigan was to freeze the senate seats on a geographical basis, but retain the popular representation in the lower house, in effect giving the rural areas a veto on state legislation. The cases also differ in that in Baker v. Carr the inaction of the legislature was in contravention of the provisions of the state constitution, while in Scholle v. Hare the scheme was provided for in the state constitution itself.

By a five-to-three vote, the Supreme Court of Michigan denied the relief sought. The court was split into several factions. Four of the eight members thought that there was no infraction of the equal protection clause. Three thought that there was. The remaining member, Justice Black, was of the opinion that there was a violation of the equal protection clause, but, under the apportionment cases decided by the Supreme Court of the United States, it was beyond the power of the Michigan Supreme Court to correct it.

The members of the minority were of the opinion that there was no occasion to go into whether or not there is a constitutionally protected right to exact representation by population, for, like

220 Mich. Comp. Laws ch. 2, § 3 (Mason Supp. 1943). 
Mr. Justice Clark later, in regard to the Tennessee apportionment scheme, they saw complete lack of rational pattern. They distinguished the case of the United States Senate apportionment in the federal constitution as a representation of pre-existing sovereign units. In the Michigan system, on the other hand, they took the districts to be simple creation of arbitrary lines.

The Scholle case was decided on appeal by an eight-man Supreme Court. ${ }^{221}$ A majority of five members delivered a five-line per curiam opinion, remanding the case to the Supreme Court of Michigan for reconsideration in the light of what had been said by the Court in Baker v. Carr. Mr. Justice Harlan dissented. ${ }^{222} \mathrm{He}$ argued that four of the Michigan justices, enough to control the eight-man court, had held that there was no violation of the equal protection clause in the context of the facts of the case, without so much as mentioning the problem of jurisdiction or justiciability of the issues, leaving before the Supreme Court the single issue of whether or not the Michigan court was right in its decision on the merits. Justices Clark and Stewart concurred with the majority disposition of the case, but noted that had they agreed with their brother Harlan that the basis of the Michigan Supreme Court decision was on the merits, they might well have agreed to decide the merits without first remanding. In their view, only three of the five members voting to dismiss placed their decision on absence of the constitutional violation. All but these three, they believed, "were convinced that, whatever the underlying merits of the appellant's Equal Protection claim, it was, in the words of one of the justices, 'not enforcible in the courts.' "223 The quotation is, of course, from the opinion of Justice Black (of the Michigan Supreme Court), the fifth and doubting member of the majority. ${ }^{224}$ Since it was not necessary to have Justice Black's vote to dispose of the cause, one must believe also that Justice Edwards read the federal cases to hold absence of jurisdiction or justiciability before one can agree with Justices Clark and Stewart. As Mr. Justice Harlan suggested, this is quite difficult.

The case was decided by a majority of five, so the votes of Justices Clark and Stewart were not needed, and the significance of their concurring opinion lies only in whatever hint it gives of their views as to the extent of the holding in the Baker case. We

\footnotetext{
221 Mr. Justice Whittaker took no part in the decision.

222369 U.S. at 430 (Harlan, J., dissenting).

223 Ibid.

224 Scholle v. Hare, 360 Mich. I, 104 N.W.2d 63 (1960).
} 
already know the views of Mr. Justice Stewart, for he made them explicit in his Baker opinion. Mr. Justice Clark, on the other hand, had said that in Baker, "The majority appears to hold, at least sub silentio, that an invidious discrimination is present. . . ."225 Since Mr. Justice Douglas agreed with Clark's view that a case of invidious discrimination had been made out, there may have been a clear majority for that position. In joining his brother Stewart in Scholle, remanding solely on the ground that the Michigan Supreme Court may have decided that case under the influence of the non-justiciability doctrine, he seemed to be willing to go along with the Stewart view of the narrow holding in Baker. ${ }^{226}$

The role of Mr. Justice White is of interest, for, as noted earlier, his views and those of Mr. Justice Goldberg could determine the Court's ultimate decision, even if it is assumed, with Mr. Justice Stewart, that the merits were not determined in Baker. He was not on the Court when the Baker case was decided, and may have thought it better to put off consideration of Scholle until the next term to avoid a decision by another "bobtailed" Court, in view of the legacy of dispute left by both Colegrove ${ }^{227}$ and Baker. On the merits of the Scholle claim, it is interesting to speculate on the outcome. Under Mr. Justice Douglas's requirement of substantial equality of representation flowing from the equal protection clause, a good case can be made that the representation of the plaintiff in the Michigan senate is not "substantially equal," the ratio between top and bottom being approximately 6.5 to 1 . There remains, however, the fact that plaintiff's representation in the lower house is approximately equal. The counties comprising the smallest senate district have a total 1.75 lower house representatives for a population of 61,008 , while Oakland has six representatives for a population of 396,001 . So there is still nearly a two-to-one difference in the number of persons represented by one seat. On the other hand, the statewide proportion is one seat per 57,925 persons, so the Oakland representation in the lower house is within a fraction of that. As to the lower house, then, his claim, if any, would have to be that there are other counties which are under-represented, or that substantial equality includes some particular major fraction rule. This leaves the plaintiff's claim as one of under-representation in one house, an issue

225 Baker v. Carr, 369 U.S. at 261.

226 Id. at 265.

227 Colegrove v. Green, 328 U.S. 549 (1946). 
not posed in any of the cases, and one on which Mr. Justice Douglas has not had occasion to express himself.

From the fact that they have joined in dissent down through the years, it may be assumed that Justices Black and Douglas can be counted together. Mr. Justice Clark, on the other hand, placing his vote in Baker on the existence of a completely whimsical classification, and distinguishing South v. Peters on the existence of logical pattern, might find pure whimsy in Michigan, or might not. The overall plan of giving popular representation in one house and geographical representation in the other is, of course, the federal pattern. The view of the dissenters in Scholle $v$. Hare that the state case is distinguishable from the federal pattern because of the fact that in the national government representation was given to existing sovereign units, whereas the definition of senate districts in Michigan was a mere ipse dixit of the amendment is not exactly borne out by the facts. With the exception of two changes, these are the districts which have existed for thirtytwo years. Since the term of office under the Michigan constitution is two years, this means that the people in the various districts have pitched their political organization according to these district lines for sixteen elections. This alone appears to give selection of these districts plausibility. Nor do the two changes detract from the reasonableness of this selection. In both cases, districts are split in two by separating out counties deemed to require individual seats in the senate. The plaintiff is in a particularly poor position to argue that the changes contribute to whimsy, because his is one of the counties selected for such increase in representation. Further, Mr. Justice Clark seemed impressed by the crazy-quilt pattern in Tennessee, where some single counties had representatives, some had only influence in electing representatives in larger districts, and some had both. In Michigan there is no such complex overlapping of districts. There are thirty-four districts, each separate from the others. The thirty-four include the whole state. Of course it is true that they are not all single-county districts, but, since there are thirty-four senators and eighty-three counties, this seems to be necessary. Except in Wayne, no county is split, and in no instance are county lines crossed in drawing district boundaries. The obvious convenience in the design of county election machinery no doubt relieves this pattern from the area of mere whim, and, conceding that, the design of districts which will not cross county lines is bound to involve some degree of difference in representation ratio. 


\section{W.M.C.A. v. SIMON}

The third of the 1962 Supreme Court decisions relating to legislative apportionment was W.M.C.A., Inc. $v$. Simon, ${ }^{228}$ a suit brought to invalidate the New York apportionment of both house and senate made under provisions of the New York state constitution. These provisions are different from those in Tennessee in that the asserted rural bias is required by the constitution itself, and different from those in Michigan in that in New York no districts are directly defined. The General Assembly is called upon to apportion according to a formula set out in the constitution. The formula for the house allots one representative for each of the state's sixty-two counties, regardless of population, an additional member for each county which has more than a ratio and a half, and the balance are distributed to the counties having the highest remainder in the order thereof. ${ }^{229}$ The formula for the fifty-member senate requires the creation of fifty districts in which no county shall be split, except for the purpose of creating two or more districts within the same county, and provides that the districts so created shall be as nearly as practicable compact and contiguous and of equal population. The only limitation on the population basis of senate apportionment is the provision that no county shall have four or more senators unless it has a full ratio for each. ${ }^{230}$

The Simon case presents an interesting comparison with Baker and Scholle. In terms of the order of difference of the representation ratio as between rural and urban counties, Simon presented almost as striking a case as that demonstrated in Baker, and greater differences than were shown in Scholle. The smallest representative district, Schuyler County, has a population of 14,066, and the largest, in Bronx County, 115,000. In the senate the range is from 146,666 to 344,547 . On the other hand, the integrity of county representation being preserved, it cannot be said that, as in Tennessee, districts designed in the first instance to reflect population have lost that element of rationality by the passage of time and shifts in population, without taking on any other advertent hallmark of reasonable classification, or, as in Michigan, that the districts represent the coupling of counties in unexplainable fashion.

The case was heard by a three-judge court which held in a

228370 U.S. 190 (1962).

229 N.Y. CoNST. art. III, §§ $2-5$.

230 Id. § 4. 
two-to-one decision that there was here no irrationality which would invalidate the New York system. ${ }^{231}$ The third judge, Judge Waterman of the Second Circuit, did not pass on this point but voted to dismiss the bill on the ground that the matter was not justiciable. ${ }^{232}$

On appeal, the Supreme Court followed the pattern established in the Scholle case, remanding for reconsideration in light of the opinion in Baker v. Carr. The opinion was short and per curiam. As in the Scholle case, the majority consisted of Justices Black, Brennan, Clark, Douglas, Stewart, White, and Chief Justice Warren. This time there were no concurring opinions. Mr. Justice Frankfurter took no part in the decision and Mr. Justice Harlan dissented. The decision in the Simon case adds little or nothing to that in Scholle v. Hare; the Court referred to its "wellestablished practice of a remand for consideration in the light of a subsequent decision."233 Mr. Justice Harlan felt that two of the three judges on the three-judge court had decided the matter on the merits and the Supreme Court should proceed to the correctness of the decision. As in Scholle v. Hare, he objected to referring the case back to the district court for reconsideration without providing any guidelines for decision on the merits.

The majority read the three opinions below as resting, one on the ground of failure to state a claim, lack of equity, and lack of justiciability, the second on absence of an allegation of discrimination against a particular racial or religious group, and the third on absence of a justiciable question. "As in Scholle v. Hare ....," said the Court, "we believe that the court below should be the first to consider the merits of the federal constitutional claim, free from any doubts as to its justiciability and as to the merits of alleged arbitrary and invidious geographical discrimination." ${ }^{234}$ The last phrase serves to cast a small ray of light on the Court's Baker decision. In saying that remand will provide consideration without doubt about "the merits of alleged arbitrary and invidious geographical discrimination," the Court interprets the Baker decision as deciding that an allegation of "arbitrary and invidious" geographical discrimination states a claim under the equal protection clause, and not simply that the question is a justiciable one. It gives no hint of the Court's view as to what invidious or arbitrary geographical discrimination might be.

\footnotetext{
231 W.M.C.A., Inc. v. Simon, 202 F. Supp. 741 (S.D.N.Y. 1962).

232 Id. at 755.

233 W.M.C.A., Inc. v. Simon, 370 U.S. 190, 191 (1962).

234 Ibid.
} 
Taken together, Baker v. Carr, Scholle v. Hare, and W.M.C.A., Inc. v. Simon have made geographically-based differences in representation ratio a matter of judicial cognizance under the equal protection clause, irrespective of a showing of discrimination as to race or sex. There is nothing very shocking about this. If the geographical basis of the classification will not protect it from judicial scrutiny in the case of the fifteenth amendment violation, there seems to be no reason why it should in the case of violation of the fourteenth. Were a gerrymander based upon race, the same problems of adequate relief would present themselves. Nor is this decision inconsistent with the precedents. Conceding that the fourteenth amendment is applicable, however, it remains to apply to the geographical representation cases the ordinary principles of equal protection clause litigation.

\section{Application of the Equal Protection Clause}

A. The Nature of the Right to Representation: Poll or Point of View

This writer has suggested that division of a state into geographical subdivisions is always more of method than of substance, and any attempt to gauge the fairness or constitutionality of such a division should look to the underlying right. ${ }^{235}$ This principle is illustrated by the method the Court employed in Gomillion $v$. Lightfoot ${ }^{236}$ to distinguish Hunter $v$. City of Pittsburgh. ${ }^{237}$ The essence of the complaint in Hunter, said the Court, per Mr. Justice Frankfurter, was that if the plaintiff's property were by merger of municipal governments brought within the city of Pittsburgh, he would have to pay higher taxes. The Court said, "[I]f one principle clearly emerges from the numerous decisions of this Court dealing with taxation it is that the Due Process Clause affords no immunity against mere inequalities in tax burdens, nor does it afford protection against their increase as an indirect consequence of a State's exercise of its political powers."23s In Gomillion, on the other hand, there was no assertion that there existed "mere inequality" of voting strength, but an inequality based upon the race of the plaintiffs. Turning to the underlying right to vote, the definition of such a right depends ultimately upon one's con-

235 See Lucas, supra note 201.

236364 U.S. 339 (1960).

237207 U.S. 161 (1907).

238 Gomillion v. Lightfoot, 364 U.S. 339, 343 (1960). 
ception of the nature and operation of republican government. One simple and straightforward theory of democracy is grounded upon the assumption that majorities can in any event control by force. If one leaves decisions to force, there is a certain risk to life and limb in determining which group constitutes a majority. Therefore we count them first and avoid the bloodshed. In other words, we count polls rather than crack them. Where the entire population votes, as where issues are put to referendum, there is a certain validity to this view. Every person is taken to be the only true authority on his own self-interest and the role of the election official is not to question a man's vote, but to count it. The result has at least the virtue of representing the will of a majority of the population. Even here, a line can be drawn between minority rule and the requirement that action await more than a simple majority. Our tradition is replete with examples of the preference for inaction until the advent of a degree of consensus greater than fifty-one to forty-nine. ${ }^{239}$

Representative government adds a completely new dimension. There is no direct connection between the views of the legal representative of a particular poll, and those of its owner. This is true because, on any given issue, the views of a voter may be minority views locally. Indeed in any representative district there are to be found those who talked, worked, and voted against the legal representative. It is possible, for instance, that there are Mississippi voters who consider that a Javits or a Morse represents them better than an Eastland, or Illinois residents who consider a Byrd represents their point of view better than a Douglas. On the federal level the fact that some of the representation units are previously sovereign entities is a complicating factor because there are venerable loyalties to the state as a political unit. Even here, however, interest groups span state lines and the national management of major party efforts makes the lines even hazier. At the local level there are some local loyalties, to cities or towns, or to counties or regions. They are much less fixed, however, and it seems fair to say that there are few voters who identify their interests as primarily tied up with groups wholly within the city or county.

The problem of design in a representative system, then, is one of insuring representation to a wide variety of interests and points of view, rather than insuring simply that as a formal matter every 
person cast a vote for the same number of representatives, whether or not he has any appreciable influence in the election of any of them. Conceivably this could be done by a system which would identify interest groups and allot them representation directly: rich man, poor man, beggar man, thief. A scheme of proportional representation in a multi-party system might approximate this approach. It would raise perhaps more problems than it would solve, however, so recourse has generally been had to indirect methods of insuring interest representation.

The most workable indirect alternative is, of course, geographical districts. The assumption is that like people are apt to live contiguously, or at least that different areas of the state live with different problems, with all of which the state must deal, and that rational decision on these affairs is aided by the presence of representatives who have lived with them. Representative assemblies are, after all, only partially devices for measuring popular will; they are also deliberative in nature. It is assumed that when the views of a wide sampling of the public have been aired and discussed, action will result or not, according to rational consensus. This is not to say that there may not be issues on which consensus cannot be achieved, but rather that all representative schemes are designed only partly with an eye to the resolution of such problems. In many instances a preference has been shown for leaving them unsolved until more than a majority can be obtained in support of a particular solution. Sometimes, indeed, we have taken them out of the democratic process altogether.

The design of representation schemes obviously reflects a compromise between notions of majority rule on the one hand, and representation of a variety of points of view on the other, and where the geographical districts which serve as the basis for interest representation were designed as a secondary device, never intended to represent mere acreage or mere population, it should be obvious that their rationality cannot be measured either in hides or in heads. To state that there is a difference in population in geographical districts is to say no more than that population was not the only consideration employed in their design.

Skins are politically neutral, and presumably if the state were divided into districts as nearly square as possible, and each containing exactly the same number of inhabitants, there would be some sampling of opinion statewide. But what would result would be a weighting of the scales which would depend upon concentration or dispersion of persons with like interests. Concentration 
is to the advantage of small minority groups, for the concentrated interest is apt to be guaranteed some representation. Dispersion of interests, however, carries with it a better chance of control. Thus, in a hypothetical State with 110 inhabitants divided into ten districts each with eleven inhabitants, each interest group which can muster six votes in the same district will have a representative, while a group which can deliver a total of fifty, but no more than five in any district, will go without. Theoretically, a group with seventy-four votes could fail to control the assembly, though sixty votes properly spread could elect one hundred percent of the membership.

Life is not lived in squares and circles, and where legislatures have identified groups geographically concentrated in areas of irregular design, they have not hesitated to depart from geometric symmetry to define districts which have some political cohesion. In doing so, they show their hand, and where the group geographically delineated is one afforded particular constitutional protection, as in Gomillion, the Court will no doubt go behind the geometry. The whole pattern is complicated by the existence of general function units of government. States are divided into counties, townships, cities, and towns. Sometimes the cities are part of the surrounding counties, sometimes not. Not only is it an administrative convenience to use these pre-existing units as representation districts, but to a limited extent they represent interest groups in and of themselves, for the fact that a voter must solve many problems as a resident of a given unit gives him a certain amount in common with his fellow electors in the unit. For these reasons it is common to allocate representation with reference to county lines. This presents a complication of very real proportions. Counties vary widely in population, size, and shape, as well as in degree of political cohesion. Where a single county does not contain a sufficient number of inhabitants to justify individual representation, it is coupled with another, and the simple problem of fractions may introduce numerical inequalities as great as one hundred percent. Also, the coupling of a small county with a large one may leave the voters in the small county with little or no effective influence in an election held within the joint district. Examples of these problems can be seen in both the Tennessee and Michigan patterns. In Tennessee, Moore County is the second smallest county in the state in terms of population, and also the second smallest in area. It is surrounded by four counties, each of which has a population which is more than two-thirds of 
the portion, entitling it, under the state constitution, to have a separate representative. In some other areas, overlapping districts have been created, and that could have been done in the case of Moore. For instance, Moore could have been coupled with one of the others in a so-called floterial district. But all the other four are already over-represented because of the two-thirds fraction rule dictated by the constitution of Tennessee. The smallest of the four, Coffee County, has a voter population of 13,406. Moore County has a voter population of 2,340 . If there is any significant difference between the interests of residents of Moore and Coffee counties, that of the Moore residents would always be subordinated to that of the Coffee residents. Thus the effect of coupling Moore County with Coffee is in practical terms to permit Coffee County, with only roughly two-thirds of the portion, to elect two representatives, while leaving the residents of Moore County with no effective power to select any. Since we have seen that the political alignment of interests does not necessarily follow along county lines, the reverse may be true. If political views are in delicate balance in the four surrounding counties, and monolithic in Moore, appending Moore to any other county might have the result of changing these balances completely.

In Michigan, the smallest of the senate districts is the thirtysecond. It consists of Baraga, Houghton, Keweenaw, and Ontonagon counties which are located at the western end of Michigan's Upper Peninsula on Lake Superior. The Upper Peninsula includes 29 percent of Michigan's land mass. It is separated from the Lower Peninsula by five miles of water, recently spanned by the Mackinac Bridge. The population of the Upper Peninsula, according to the 1960 census, is 302,648 . If the exact portion were applied to the Upper Peninsula as a unit, it would be entitled to one and two-thirds senators, or if a major fraction formula is applied, to two. Under the provisions of the 1952 amendment, it is given three. In view of the fact that it is a large and sparselypopulated area separated from the balance of the state by water, and remote from the more heavily-populated portions of the state, can it be said that it is palpably unreasonable to provide it with representation no more disproportionate than that? If it is conceded that it would not be arbitrary to assign three senators to the Upper Peninsula, what of the distribution of the three senate seats in this area? What has been done is to split off the Keweenaw Peninsula area (with a population of 61,008 , and including the four counties mentioned above) as one district; roughly the 
western half of the remainder of the Upper Peninsula, containing 117,233 inhabitants and four counties, as the second (the thirtyfirst senatorial district); and the eastern half with a population of 124,407 , and seven counties, as the third (the thirtieth senatorial district). Since the thirty-second district is surrounded on three sides by water and extends sixty-five miles into Lake Superior, one could guess at all manner of special interests which might be shared by the inhabitants of this area, and which would not be represented in the state senate at all were the area to be coupled with enough of the southern or eastern counties in the Upper Peninsula to make the district contain a full portion of population. The situation is made worse by the physical location of the counties in the thirty-second, for it cannot be joined with any group of counties not contiguous to it.

Of course it is true that leaving apportionment to a legislative assembly which represents at any given time a particular alignment of political interests is, in a sense, if one may paraphrase Bentham's remark about the elevation of practicing attorneys to the bench, to make a procuress mistress of a girls' school. As we have seen, without regard to equal numbers within a district a minority of thirty-six can control a majority of seventy-four, where a 110-person universe is divided into ten districts and enough ingenuity is employed in drawing the district lines. This means that a majority may perpetuate its control until it drops below the number required to control fifty-one percent of the votes in fifty-one percent of the districts. With unequal districts, theoretically even this floor disappears. Unless it appears that this nadir has been reached, however, or that the Constitution requires formal equality, there seems to be no difference between effective disfranchisement of interest groups through ingenuity in drawing the district lines on the one hand, and differences in the number of persons residing in the various districts on the other.

Since it has been suggested in none of the apportionment cases that disfranchisement has proceeded this far, we are left with the existence of the requirement of numerical, or formal, equality. In a number of places it has been shown that there is no historical justification for the statement that the Constitution required such equality, either at the time of its adoption, or after the adoption of the fourteenth amendment. This does not mean that the concept of equal protection might not grow to include such a requirement, for, as the Court said in the Brown case, it came to the conclusion that education had changed in importance, and that even 
though it might be conceded that earlier Courts would not require unsegregated schools, that did not foreclose this one from reading the effects of segregation in the light of what we know about it today.

In the area of representation, can any practical argument of change of circumstances be marshalled to justify the requirement of formal equality in representation districts? A good case can be made for the directly opposite proposition. When city populations were a small minority interest in most state affairs, direct intervention in their local affairs was common. In the middle of the nineteenth century state legislatures provided a city hall for Philadelphia, in Maryland controlled the purchase of such ordinary city equipment as an individual fire engine, and in New York and elsewhere set up special commissions to take over local police administration. ${ }^{240}$ Today virtually every state has adopted constitutional limitations on the enactment by state legislatures of "local" legislation. ${ }^{241}$ Many states have protected the urban management of local affairs through constitutional home rule provisions, ${ }^{242}$ and, as a general pattern, legislative action with respect to cities and towns has steered an unswerving course toward greater local power. ${ }^{243}$ As city populations have grown, they have had an ever-increasing impact upon statewide elections, and it must be remembered that control of the governor's mansion carries with it control of the executive veto, and the not inconsiderable power to control executive discretion and to make an everincreasing number of appointments. In addition, cities have wielded an enormous power in the selection of national officers. It may be presumed, for instance, that since Senators are chosen on a statewide basis, an urban majority within the state can control their election.

As urban populations have grown to and beyond half the population in some states, the problem has been one of whether this particular grouping of interests shall be permitted to control the entire state. Its desire to do so, in addition to the usual motives of power and patronage, may have stemmed to some extent from the fact that general function districts have often been out of line with living arrangements, and cities have felt that the efficient management of the affairs of large metropolitan areas can

240 See Pate, Local Government \& Administration 60 (1954).

241 See Index Digest of State Constrtutions 939 (2d ed. 1959).

242 See $i d$. at 714.

243 Indeed, frequently the powers of cities under legislative charters or optional charter laws are greater than under many of the home rule provisions. 
be accomplished only by such control. Home rule, they feel, is not enough, because it does not permit coercion of areas outside the governmental unit. Control of the legislature often carries with it control of the design of units of local government, and, even where it does not, it is often necessary for effective efforts to amend the state constitution.

It should be stated here that the disproportion in representation between urban and rural areas is not by any means the only limit to the absolute exercise of the powers of majorities within the states, or within the national government. A requirement of more than a majority to propose or adopt at referendum a constitutional amendment, or to incur obligations, is also in the teeth of the concept that wherever a group of political interests can control fifty-one percent of the votes within the political unit, it may force its will upon the minority. ${ }^{244}$ Home-rule provisions, long the objective of urban populations, limitations on the power to tax, and a host of other strings tied to the legislature's power to rule, are all cut from the same cloth. Nor is disproportionate representation a single class, for the bargain can be drawn in a number of ways. In the United States government it is in the nature of a veto. Geographical minorities are protected by overrepresentation in the Senate, while majorities are protected in the House of Representatives. This is a pattern followed in several of the states, and indeed, the pattern adopted by the people of Michigan when they approved the constitutional amendment of 1952. In Tennessee, geographical apportionment, as amended by the passage of years, preserves in the rural areas the power to rule absolutely, though even there the statement can be made only with respect to these two of the many alignments which no doubt exist. Since the senate districts are different from those employed in the lower house, different interests may be represented in one than in the other. For instance, to the extent that their interests are different from those of the city of Knoxville, the residents of Roane County are not in a position to elect a representative to the Tennessee senate, for they are placed in a senate district including that city, and the Knoxville voting population constitutes nearly seventy percent of the total. In the lower house, on the other hand, Roane constitutes a single-county district.

As between urban and rural areas, the allocation of seats in the senate on a basis other than by population, coupled with a lower house apportioned on the basis of population alone, is 
nothing but a compromise made necessary by the fact that the unit for democratic action was determined at a time when there was a better balance between interest groups and population, and the assumption could be made that on most issues the fifty-one to forty-nine vote would be acceptable to the minority. As an increasingly large proportion of the state's population has become concentrated in cities and highly interested in the problems of cities, this minimum degree of homogeneity has become doubtful and the people have decided that it is better to operate by stalemate and bargin as a process for achieving consensus at a higher level.

In summary, though there may be an abstract right to participate in general elections in whatever political units one finds one's self, the very nature of representative government based upon geographical selection places some voters on one side and some on the other. Therefore, there will always be voters whose viewpoint or political stamp will not be represented by the person selected to represent him in the legislative council. If one views the right to representation as a device for achieving expression of the voter's view, and further as a right personal to each voter, the right is not one susceptible of full vindication in any system of representative government based upon representation of geographical areas, and even its approximation is made impossible by a requirement of compactness, contiguity, and districts of equal population. Such a system would simply substitute the cast of the dice in terms of concentration and dispersion for some more reasonable effort to see that a wide variety of points of view achieve representation in legislative deliberations. The requirement of equality of populations within districts, uncoupled with a requirement of compactness and contiguity, would place a floor under the number of votes required to control the political institutions in a given jurisdiction, the floor being half plus one of the number of votes in one district times half plus one of the number of representative districts. This may be desirable in itself, but the advantages should be weighed against the drawbacks. There are administrative reasons for preferring compactness and contiguity of districts where possible, and the coupling of general function and representative districts. The requirement of equality of numbers may face the legislature or the constitutional convention with a choice between the efficient operation of the election process and the desire to see to it that important but geographically dispersed segments of the population find expression in legislative 
deliberations over the affairs of the state. It should also be noted that there has never been a showing that geographical representation not precisely equated to population as a practical matter has ever resulted in control by so small a minority. Its interdiction, then, may result in positive disadvantages without any concomitant practical advantage.

\section{B. The Function of the Federal Courts}

It is obviously within the power and the duty of the Supreme Court to determine whether or not the equal protection clause requires equality of population within representation districts. History indicates that it does not. ${ }^{245}$ Present practice indicates that it does not. The precedents of the Court indicate that it does not. ${ }^{246}$ Finally, four of the eight Justices sitting in Baker $v$. Carr have stated that it does not. ${ }^{247}$

But this is not to say that no problem remains under the equal protection clause. By way of analogy, Mr. Justice Frankfurter stated in his Gomillion opinion that the equal protection clause does not afford protection against mere inequalities in tax burden. ${ }^{243} \mathrm{He}$ would not gainsay, however, that the Court will examine a tax statute where it is alleged that invidious discrimination among taxpayers similarly situated underlies the tax. ${ }^{249} \mathrm{He}$ simply stated the rule that where there is no requirement of precise equality, an allegation of the lack of it makes no case under the fourteenth amendment. He suggested, for example, that were the state to arrange its representation system so as to discriminate against Negroes, or Jews, or red-headed people, the equal protection clause would come into play. ${ }^{250}$

Mr. Justice Douglas suggested that a showing that the differences in representation ratio between areas are very great is in itself enough to require that the plaintiff be afforded an opportunity to prove "invidious discrimination." This view also has

245 See, e.g., the historical material in the Frankfurter dissent in Baker v. Carr, 369 U.S. at 302-24. See also the opinion of Edwards, J., in Scholle v. Hare, 360 Mich. at 85 , 104 N.W.2d at 107.

240 E.g., MacDougall v. Green, 335 U.S. 281 (1948).

247 Justices Clark, Harlan, Frankfurter, and Stewart. The views of Mr. Justice Brennan and the Chief Justice are unknown. Presumably Justices Black and Douglas believe that the Constitution requires substantial equality of representation, though even Mr. Justice Douglas states that there is room for weighting. See text supra at 748 . 248 Gomillion v. Lightfoot, 364 U.S. 339, 343 (1960).

249 E.g., Mr. Justice Frankfurter joined the majority in Wheeling Steel Corp. v. Glander, 337 U.S. 562 (1949), and in Township of Hillsborough v. Cromwell, 326 U.S. 620 (1946).

250 Baker v. Carr, 369 U.S. at 300 (Frankfurter, J., dissenting). 
analogies in the cases decided under the equal protection and commerce clauses. Thus differences in tax treatment of outsiders which are small enough plausibly to be taken as efforts at equalization of burden or necessary to assure collection may pass muster, while large inequalities may show by their very size that they are intended to place the outsider at a competitive disadvantage. ${ }^{251}$ But these cases can be said to rest upon the fact that the insideroutsider classification is a prohibited one, and the degree of the difference is an element in proof that the prohibited classification is the one which was employed. The equal protection cases dealing with distribution of tax burdens within the state indicate that a necessary element of the plaintiff's case is a showing not only that he is treated differently from other taxpayers, but that he is treated differently from those similarly situated. If the Court is convinced that property is of a different kind or character, for instance, differences in tax rate will not be corrected. ${ }^{252}$ Similarly, where a tax is levied upon one business or activity, the Court will not insist that it be levied on another. ${ }^{253}$ In these cases the degree of difference is not important. If the state may classify property into real and personal, tangible, railroad property, machinery and tools, etc., and may apply different rates to each, then it may make these differences in rate small or large, as it sees fit, or indeed may tax some and leave others untaxed. If a state may classify two businesses into different classes, then it may levy high taxes on one and none at all on another. ${ }^{254}$ These cases are different from those involving the determination of proper classes because the general distribution of tax burden is thought to be one largely of legislative discretion. The allocation of benefits also comes under this heading. Before a citizen can persuade a court to interfere with the state's decision to pay benefits to some, or provide services to others, it must be shown that the class is improper. If the class is a permissible one, the amount of the benefit, or the degree of dif-

251 See, e.g., Hanover Fire Ins. Co. v. Harding, 272 U.S. 494, 516 (1926).

252 See, e.g., Charleston Fed. Sav. \& Loan Ass'n v. Alderson, 324 U.S. 182, 191 (1945). See also Ohio Oil Co. v. Conway, 281 U.S. 146, 159 (1930).

253 See, e.g., the statement of the Court in Allied Stores, Inc. v. Bowers, 358 U.S. 522, 526-27 (1959): "The State may impose different specific taxes upon different trades and professions and may vary the rate of excise upon various products . . ." and see the cases cited therein. See also Sholley, Equal Protection in Tax Legislation, 24 VA. L. REv. 229 (1938).

254 In Fox v. Standard Oil Co., 294 U.S. 87 (1935), the amount of the tax was $\$ 240,000$. In Great Atl. \& Pac. Tea Co. v. Grosjean, 301 U.S. 412 (1937), the tax on a local merchant operating ten grocery stores was $\$ 10$ each, while the tax on a national chain with 600 , operating only one in Louisiana, was $\$ 550$ for that one. See Sholley, supra note 253 , at 255 . 
ference between services provided, is within the discretion of the state.

Generally, geographical differences have fallen into this second category of cases, for the reason that the differences between populations situated in different areas are so many that it is impossible to say that there exists no reasonable basis for the classification. Occasionally, as in the case of racial discrimination, or in the definition of special assessment districts, it is possible to see through the geography to identify an impermissible classification. ${ }^{255}$ In the annexation cases, on the other hand, the burdens and benefits of living within the city limits are so hard to identify and quantify that the Court has been reluctant to attempt the task of weighing them. ${ }^{25 \theta}$

This is not to say that geography per se is a proper basis of classification. Where the Court is able to identify geographical areas identical in every respect germane to the purposes for which the classification was made, it sometimes has inquired into the legality of differences in treatment. If the city zones one area differently from another without any supporting differences in situation, it runs the risk of unconstitutionality. ${ }^{257}$ Hypothetically, if it were to split a single tract of identical residences into two zones and apply one tax rate to one and a higher to another, can there be any doubt that the Court would apply the usual standards of tax equality? ${ }^{238}$

Applying Mr. Justice Douglas's reasoning in his Baker opinion, there is no rationality in treating one voter differently just because he lives in one place or another. Where the differences in representation are small, it may be assumed that some other good

255 See, e.g., Gomillion v. Lightfoot, 364 U.S. 339 (1960). See also Myles Salt Co. v. Board of Comm'rs, 239 U.S. 478 (1916).

256 See, e.g., Texas ex rel. Pan Am. Prod. Co. v. City of Texas City, 355 U.S. 603 (1958). See also Comment, 26 U. ChI. L. Rev. 279, 315-17 (1959).

257 See, e.g., Nectow v. City of Cambridge, 277 U.S. 183 (1928), reversing 260 Mass. 441, I57 N.E. 618 (1927). In the zoning cases the issue is generally framed as one of the reasonableness of a land-use limitation, rather than as one of equality of treatment. In cases in which the forbidden use is permitted to property owners whose premises are cheek and jowl with the restricted parcel, however, it could be framed as a denial of equal protection rather than due process. See De Lano v. City of Tulsa, 26 F.2d 640, 645 (8th Cir. 1928). There the rejection of the equal protection argument as applied to the facts of the case illustrates the difficulties of controlling the exercise of powers involving broad discretion. "Equality of protection of the law in such cases requires consideration of the relative conditions as applied to the particular property and other properties and locations within the scope of the ordinance." Id. at 645-46.

258 Cf. People ex rel. Schlaeger v. Allyn, 393 Ill. 154, 65 N.E.2d 392 (1946), brought under the Illinois constitutional requirement that property taxes be levied ad valorem. In the Schlaeger case the inequality of the effective rate was brought about by differences in ratio of true to assessed value in two different counties, and the court relied upon the factual nature of the assessment process to justify its refusal to intervene. 
and sufficient reason may support them. Where they are grossand Mr. Justice Clark would add, where they appear randomthere arises a presumption that they are not justified by any difference in situation germane to the purpose of the classification. Certainly it might be conceded that were his horribles to take place, for example, were the city of Memphis to be split into two wards, one with a population of 10,000 and the other with a population of 386,000 , and the first were given ten seats on the municipal council and the second, one, the difference would be hard to rationalize on the basis of any legitimate objective of representative government.

But this is to say only that there comes a point beyond which differences of degree become differences of kind. By way of analogy to the tax and regulation cases, either a tax or a regulation can be so onerous to a given calling or property owner so as to be treated as a prohibition or confiscation. When this point is reached, the Court will inquire into the power to prohibit or the power to seize. ${ }^{259}$ In like fashion, a difference in representation might at some point be looked upon as a disfranchisement in disguise. In such a case, surely the Court would shift the inquiry from one governed by permissible standards of distribution to one governed by standards of exclusion. ${ }^{260}$

Difficulties of relief remain, regardless of the substantive standard employed. Of course the federal courts should avoid affront to the processes of the state wherever it is possible to do so. And Mr. Justice Frankfurter is no doubt correct in asserting that courts are sometimes faced with situations which make any available mode of relief worse than the evil they are designed to correct. This is not always true, however. In the Gomillion case, for example, the declaration of invalidity of the Alabama statute had the result simply of effecting a return to old district lines. As the Illinois history suggests, this may be worse than nothing in the case of long failure to redistrict. It is not true that all such cases

259 Where there is the power to prohibit, of course, the fact that taxation is employed as the method of effecting the prohibition will not invalidate the exercise of the power. See, e.g., Rast v. Van Deman \& Lewis Co., 240 U.S. 342 (1916). There the Court was not convinced that the tax in question was prohibitory, but went on to say that, assuming that it was, the business taxed (coupons redeemable in merchandise) could be prohibited consistent with the due process clause.

260 Complete exclusion from representation on the basis of geography has been rare, but there have been such cases. See People v. Maynard, $15 \mathrm{Mich}$. 463 (1867). See also 2 Cooley, Constiturionar Limitations 1394 (8th ed. 1927). In the Maynard case, the legislature had created a new county by splitting off from another county one whole township and parts of two others. The court said the effect of this would be to permit the whole township to elect the entire governing board, depriving the residents of the scraps of their votes in county elections. It held that this would be in violation of the state constitution. 
present the same difficulties. In the congressional reapportionment cases, federal statutes cover the case by providing for elections at large. In the Georgia county unit system cases, the primary laws could be saved without the offending method of counting the votes. Equitable relief is discretionary to a large extent, and the Court can control any absence of good sense which district courts from time to time might display. It goes without saying that $\mathrm{Mr}$. Justice Frankfurter was correct in suggesting that the federal courts should refrain from simply shouting down a rain barrel and should limit their activities to the correction of evils amenable to judicial methods. This they will do if they follow the general principles of equal protection litigation. It remains to be seen whether the district courts will adhere to these general guides or will read Baker v. Carr as a license to supervise legislative apportionment to the end of achieving a system consonant with their own notions of a proper polity. So far, evidence is limited and conflicting.

\section{Post-Baker Developments}

\section{A. The Baker Case on Remand}

In appraising the reaction of the federal district and state courts to these cases in the light of the Baker, ${ }^{261}$ Scholle, ${ }^{262}$ and Simon ${ }^{263}$ opinions, it is useful first to follow those three cases on remand.

The subsequent history of Baker $v$. Carr vindicates Mr. Justice Clark's view on the necessity of remand for trial. At a pre-trial conference the Attorney General of the state appeared and stated that he was authorized to advise the court that the Governor of Tennessee would issue a call for a special session of the legislature to consider the question of reapportionment in view of the holding of the Supreme Court. He then moved for a stay of proceedings until the General Assembly could be convened and could act upon the matter. ${ }^{204}$ The court reserved its ruling on the motion, and June 11, 1962, was set as the date for further hearing. By June 7, the General Assembly had enacted legislation reapportioning the membership of both the senate and lower house, and this legislation had been signed by the governor.

The district court began its consideration of the new Tennessee apportionment acts by patching together a standard from snip-

201 Baker v. Carr, 369 U.S. 186 (1962).

262 Scholle v. Hare, 369 U.S. 429 (1962).

203 W.M.C.A., Inc. v. Simon, 370 U.S. 190 (1962).

204 See Baker v. Carr, 206 F. Supp. 341 (MD. Tenn. 1962). 
pets from the various opinions in the Baker case. It noticed that Mr. Justice Clark felt that the original Tennessee scheme was wholly irrational and arbitrary, and linked Mr. Justice Stewart to this view because of language in his opinion describing the complaint, despite the fact that Mr. Justice Stewart refused to call the scheme arbitrary and carefully limited his decision to the justiciability of apportionment questions. It quoted from Mr. Justice Douglas to the effect that the equal protection clause prohibits invidious discriminations, and stated that "there can be no doubt that the majority of the Supreme Court ruled in this case, as stated by Mr. Justice Clark, at least $s u b$ silentio, that invidious discriminations were present in the 1901 reapportionment statute and that it fell far short of the standards of the equal protection clause."205 It also quoted from the Brennan opinion this further characterization of the complaint, "the injury which appellants assert is that this classification disfavors the voters in the counties in which they reside, placing them in a position of constitutionally unjustifiable inequality vis-à-vis voters in irrationally favored counties," ${ }^{200}$ added Mr. Justice Douglas's reference to "egregious injustices," them all together, and came up with this question: "Do the statutes establish classifications predicated upon a rational basis, or are they utterly arbitrary and lacking in rationality?" ${ }^{288}$ This is, of course, the Clark test.

It then became necessary to inquire into whether the new apportionment acts fell within the stated test. The court conceded that in overall plan the apportionment of the lower house had eliminated or mollified some of the most glaring inequities-without reference to what these were-and that it could be explained in some of its major features upon a basis which the court was not prepared to say was within itself irrational, but added that "it nevertheless possesses some inequities and inequalities which in our opinion should be corrected or removed in order to avoid grave doubts as to its constitutionality." ${ }^{268}$ It thereupon picked out a number of instances of treatment it considered unequal, much in the fashion of Mr. Justice Clark's illustrations of lack of pattern. With the exception of two of these instances, they all relate to the fractional representation of counties in so-called floterial districts. Thus the court suggested that it is unfair to

$265 I d$. at 345.

266 Id. at 344.

267 See 369 U.S. at 250 n.5 (Douglas, J., concurring).

268 Baker v. Carr, 206 F. Supp. 341, 345 (M.D. Tenn. 1962).

269 Id. at 345. 
provide Anderson County $(33,554)$ with a single representative while Rutherford $(30,347)$ has an individual representative and also participates with Cannon $(5,235)$ and Dekalb $(6,660)$ in a floterial district. ${ }^{270}$ The other two instances of doubt were the over-representation of Sevier and Fayette counties. According to voter population they were both under the two-thirds fraction but were both given individual representation. ${ }^{271}$ The defendants argued that these two counties were given full representation because their total population would have entitled them to full representation, had the distribution been on this basis. It was said that these were the only two counties in which this would be true. The court rejected this explanation with the statement that these were the only two instances in which total population rather than voter population was taken as the basis of representation. ${ }^{272} \mathrm{Em}$ ployment of a standard of one full representative to each county which has two-thirds of the portion based upon either total population or voter population seemingly was the one employed. The court did not explain why this is not an acceptable standard under the equal protection clause. It seems to say that it is impermissible in that it applies one standard to one group, and another standard to another. This is of course arrant nonsense, for, if both total population and voter population are permissible standards under the equal protection clause, there appears no reason whatever for supposing that they cannot be used in the alternative in providing minimum representation.

With regard to the apportionment of the Senate, the court perceived Mr. Justice Clark's "crazy quilt." 273 The overall variation in ratio was about two and one-half to one. As between rural areas, the court saw a bias in favor of the eastern counties. As between urban districts, there was a difference in representation ratio as great as thirty-seven percent between Sullivan County (Bristol) and the sixth senate district-Knox and Anderson Counties (Knoxville and suburbs). The court concluded that the act apportioning the senate was "utterly arbitrary and lacking in rationality. Its only consistent pattern is one of invidious discrimination."274

There was no discussion at all of rural bias as such. No figures were given as to differences in ratio as between major centers of population and more sparsely-populated areas. As far as the ration-

$270 \mathrm{Id}$. at 346.

271 Ibid.

272 Ibid.

273 Id. at $346-47$.

274 Id. at 348. 
ale of the declaration of unconstitutionality of the acts goes, then, it is based upon Mr. Justice Clark's formula. The equal protection clause requires rational pattern and differences must not be willynilly and unexplained.

The court did not stop here, however. It proceeded to provide guidelines for the enactment of a statute which will in its opinion provide a constitutionally valid apportionment plan. The minimum standards of equality proposed by the court were these: the two-thirds rule of the Tennessee constitution can be applied to the apportionment of the house of representatives; if so, however, the apportionment of the senate must be on a true basis of population without regard to fractions; on the other hand, if there is an apportionment of the senate on a rational basis other than strict adherence to population, the house of representatives must be apportioned on a true population basis without regard to the two-thirds fraction rule. ${ }^{275}$

This is not quite the standard required by the constitution of Tennessee, but almost. The Tennessee constitution requires that counties having two-thirds of the portion must be given separate representation in the house of representatives, and further that, in apportioning senate seats, insofar as possible the fractions lost by the application of the two-thirds rule be made up to the counties with voter population above the portion. ${ }^{2 \pi 6}$

This standard leaves at large the question of what rational pattern could be employed in apportioning the senate. If one takes the court's reaction to the 1962 act apportioning the house of representatives, relatively small differences in treatment may be deemed unfair and unconstitutional. This is not to say, however, that were differences consistent with some overall formula, the court would consider that the same order of difference would constitute irrationality. Thus a system which was based upon a formula designed to reflect population density might be all right. To Mr. Justice Clark's requirement of rationality, then, the district court has added the requirement of strict population apportionment in at least one house of the legislature. Both must be rational and one must be by the poll. ${ }^{27}$

The problem of relief in Baker $v$. Carr, as in all such cases, was a puzzling one. It will be remembered that the Tennessee Supreme Court had held that, were it to declare the 1901 act unconstitutional, there would be no legal legislature to perform the function

275 Id. at 349.

270 Ibid.

277 Ibid. 
of passing a valid apportionment statute, and the state would be in chaos. Mr. Justice Douglas had tossed this problem off with the observation that the contrary opinion had been expressed by the Supreme Court of Iowa, an opinion which he said is "plainly correct." 278 The district court was somewhat more cautious. It read the decision of the Supreme Court of Tennessee in Kidd $v$. $M c$ Canless ${ }^{270}$ as holding that only where there has been a judicial determination of the illegality of a statute under which an officer holds his office such an officer cannot be a de facto officer. After expressing some doubt as to whether this is binding upon the federal courts enforcing constitutional rights, it proceeded to "find and hold" that the doctrine had no application to the expression of views of unconstitutionality by the court, where the court expressly withholds final judgment, including the "declaration of invalidity." This, the court continued, will permit legal elections to be held under the 1962 statutes, and the legislature "to act with the express sanction of the Court to effect the necessary remedial measures and consequently in 'good faith' as far as its authority is concerned." 280

This disposition of the case leaves all the issues at large until June 3, 1963, when the Tennessee Legislature will either enact an apportionment statute satisfactory to the district court, or not. The court spoke of its method of handling the situation as avoiding "a far more drastic form of relief," without specifying what that form might be. And so we leave the United States District Court for the Middle District of Tennessee and the governor and General Assembly of that no longer so sovereign state to their game of "ducks and drakes," and proceed to Michigan.

\section{B. The Scholle Case on Remand}

In the Scholle case, it will be remembered that the Michigan Supreme Court had decided in favor of the 1952 amendment by a margin of four to three, ${ }^{281}$ with the majority enjoying the vote of a fifth member of the eight-man court who was of the opinion that it was beyond the power of the Michigan court to correct the abuse. ${ }^{82}$ The case was remanded for reconsideration in light of what had been said in Baker v. Carr. It could be expected that

278 Baker v. Carr, 367 U.S. at 250 n.5. See Cedar Rapids v. Cox, 252 Iowa 948, 108 N.W.2d 253 (1961).

270 Kidd v. McCanless, 200 Tenn. 273, 292 S.W.2d 40 (1956).

280 Baker v. Carr, 206 F. Supp. 341, 350 (M.D. Tenn. 1962).

281 See text supra at 758 .

282 Black, J. 
Justice Black of the Michigan court would reverse his position and vote for a declaration that the amendment was unconstitutional. This he did. Since Justices Carr, Kelly and Dethmers had not seen a violation of the equal protection clause in the case when first heard, their view on remand might be expected to depend upon whether they took Mr. Justice Stewart at his word about the extent of the majority holding in Baker v. Carr, or, like the federal district court in Tennessee, followed Mr. Justice Clark's suggestion that the message of the majority went to the merits as well. Clearly they read the holding in the Stewart form, but added that even if one supposes Baker to rule on the merits of the constitutional claim in Tennessee, the fact that the differences in representation ratio existed in both houses there distinguishes the Michigan case. In short, Justices Carr, Kelly, and Dethmers, stuck to their guns. By the time the Scholle case was reheard, Justice Edwards had left the court. If, as Mr. Justice Harlan suggested, the Edwards opinion had been grounded flatly on the merits, this change in court personnel had the effect of destroying the majority of four. In this connection it is worthy of notice that Edwards' place was taken by Justice Adams, the former attorney general of the state who had argued the case before the original Scholle court. Because of this connection, Justice Adams disqualified himself. Though of course one cannot be certain that an advocate's views will follow him onto the bench, ${ }^{283}$ the decision of the court after the second Scholle hearing, resting as it does on a majority not large enough to grant relief where the full court is sitting, does not say the last word on the standards to be applied in measuring the rationality of senate apportionment. ${ }^{284}$ If the Michigan constitution were subsequently amended to provide a senate plan in all respects similar, it is by no means certain that the court would strike it down. ${ }^{285}$

283 See, e.g., The License Cases (Thurlow v. Massachusetts), 46 U.S. (5 How.) 504, 575 (1847), where Mr. Chief Justice Taney eats the arguments he had made in Brown v. Maryland, 25 U.S. (12 Wheat.) 419 (1827). But Mr. Chief Justice Taney had twenty years in which to convince himself that he was wrong.

284 In the November 1962 election, Justice Adams was replaced by Justice O'Hara, leaving the Michigan court split evenly between Democrats and Republicans.

285 Under the proposed new constitution of Michigan, to be submitted to the voters on April 1, 1963, and if approved, to take effect on January 1, 1964, the lower house would be apportioned among 110 single-member representative districts substantially according to population. Counties containing seven-tenths of one percent of the state's population would be entitled to separate representation. The senate would be apportioned among thirty-eight single-member districts on the basis of apportionment factors. The apportionment factors of each county would be determined by taking the sum of its percentage of the state's population multiplied by four, and its percentage of the state's land area. Reliance upon legislative apportionment would be abandoned in favor 
In granting relief the Michigan Supreme Court was not so cautious as was the district court in Tennessee. The new attorney general, reversing the position taken by his predecessor, had dropped the argument on the merits, and had asked that the whole matter be postponed until the state legislature could enact a new senate apportionment. The majority of the court did not follow this suggestion. It declared the 1952 amendment unconstitutional and enjoined the holding of the August 1962 primaries under its provisions. ${ }^{280}$

The second Scholle decision by the Michigan court was handed down on July 18, 1962. The primary elections were scheduled for August 20. Application for stay of the state court's order was made to Mr. Justice Stewart, to permit application for certiorari to review the decision, and the stay was granted. Certiorari has been applied for, ${ }^{287}$ so the Michigan apportionment scheme, and the general question of geographical representation in one house balanced by popular representation in the other, will be back before the Court this term, assuming, of course, that the question is not ducked by a denial of the certiorari petition.

\section{G. The Simon Case on Remand}

W.M.C.A., Inc. v. Simon ${ }^{288}$ was reheard by the same threejudge court which decided it initially. This time Judge Waterman joined in the decision that the New York constitutional provision and the apportionment enacted under it on the merits do not violate the equal protection clause. From Baker $v$. Carr and the various cases decided by the district courts since the Baker case, Judge Levet formulated five tests: (1) rationality, (2) presence of a historical basis, (3) existence of possible remedies if gross inequality exists, (4) geography, including accessibility of representatives to their electors, and (5) whether the court is called upon to invalidate solemnly enacted state constitutions and laws. ${ }^{289}$

Applying these tests to the facts in New York, Judge Levet saw nothing irrational about the New York formula, providing, as it

of decennial apportionment by an eight-member bipartisan commission, with provision for an additional two members in the event that a third party polls $25 \%$ of the gubernatorial vote at the last general election at which a governor was elected preceding each apportionment.

280 Scholle v. Hare, 367 Mich. 176, I16 N.W.2d 350 (1962).

28731 U.S.L. WeER 3147 (U.S. Oct. 15, 1962) (No. 517).

288208 F. Supp. 368 (S.D.N.Y. 1962), appeal docketed, 31 U.S.L. WEEK 3132 (U.S. Sept. 26, 1962) (No. 460).

280 Id. at 374. 
does, minimum representation to each county. He found that there is sound historical reason for choosing the county as the unit of representation. As an available remedy he pointed out that the New York constitution provides for a referendum every twenty years on the question of calling a constitutional convention, and further that in 1957 such a vote was taken after announcement by Governor Harriman that the most urgent constitutional reform needed was "to elect one house of the legislature on the basis of population to give big cities fuller representation." Although the ten most populous counties contain 73.5 percent of the citizen population of the state, the vote was against the call. Were the call to issue, three delegates would be chosen from each senate district, and fifteen from the state at large. This means, says Judge Levet, that at a constitutional convention the ten most populous counties might well control.

As to geography, the court thought that the very large size of some of the up-state New York counties, contrasted with the small size and high concentration of population in the counties in New York City, created problems militating against apportionment on a strict population basis. The choices become whether one increases the total number of assemblymen-already 150 -to the point of making discussion less productive, or creates districts so large that the representative loses touch with his constituents. ${ }^{290}$

Finally, Judge Levet reiterated the presumptions against the invalidity of state laws and constitutions, suggesting that it must be a plain case in which a federal court will act to invalidate such provisions.

Judge Ryan wrote a brief separate opinion concurring in the findings of fact and conclusions of law stated by Judge Levet, and concluding that the court has jurisdiction, that this jurisdiction has been exercised, "and, after trial and examination of the statutes involved ... the complaint herein should be dismissed upon its merits."291 Judge Waterman also concurred in Judge Levet's findings of fact and conclusions of law, and with his colleagues in dismissing the complaint on the merits. ${ }^{292}$

This leaves W.M.C.A., Inc. v. Simon ready for the Supreme Court. At least everyone has agreed that it was disposed of on the merits-every judge on the three-judge court felt the necessity to state this fact explicitly. Appeal lies directly to the Supreme 
Court. The case has not been frozen in the lower court like Baker v. Carr. It seems probable, therefore, that before final settlement of the latter, the Simon case will reach the Supreme Court. If the district court is upheld in its determination that there is no unconstitutional discrimination in New York, the minimum representation formula may rapidly become the universal pattern. It should be noted that, while there is a large top-to-bottom variation in ratio in New York, the urban voters have a majority of seats in both houses, and the rural bias is not very great. New York City, for instance, has a population which constitutes 46.0 percent of the population of the state; it elects 43.3 percent of the total number of assemblymen, and 43.1 percent of the total number of senators. The ten most populous counties in the state, with 73.5 percent of the citizen population, elect 65.5 percent of the senators, and 62.0 percent of the assemblymen. The complaint is not in the nature of a challenge to rural domination, but an urban attempt to increase a majority on the theory that direct proportion to population is required. How far differences could be stretched by minimum representation and fall within the reach of the Simon decision is doubtful. In Tennessee, for instance, where there are ninety-five counties, and the constitution places a limit of ninetynine on the number of representatives, the application of a minimum representation of one representative per county would leave only four to be distributed on a population basis. In New York, on the other hand, there are only sixty-two counties and there are 150 assemblymen, leaving eighty-eight to be distributed among the more heavily populated counties.

The Simon court was much less concerned about individual differences than was the district court in Tennessee on the Baker remand. While the latter found that a difference of four to one in the population of single districts demonstrated invidious geographical discrimination, ${ }^{293}$ the New York federal district court passed off a two-to-one difference in the number of persons residing in the largest and smallest senate district with the following remark: "No proof was submitted by plaintiffs that the senatorial districts, aside from some variance in citizen population were otherwise subject to criticism. The system is not irrational. It clearly gives weight to population within the state's counties which forms a basis for the ingredient of area, accessibility and character of interest," 294 and held rational and valid a lower house apportion-

203 Baker v. Carr, 206 F. Supp. 341 (M.D. Tenn. 1962).

204 W.M.C.A.,Inc. v. Simon, 208 F. Supp. 368, 376 (S.D.N.Y. 1962). 
ment in which the difference in population between the largest and smallest district was fourteen to one.

\section{Other Representative District Court Gases: Into the Thicket with Abacus and Pruning Hook}

\section{A. Trilogy in Georgia}

First of the post-Baker filings was Sanders v. Gray. ${ }^{205}$ Like Cook v. Fortson (Turman v. Duckworth), ${ }^{296}$ South v. Peters, ${ }^{207}$ Cox v. Peters, ${ }^{298}$ and Hartsfield $v$. Sloan, ${ }^{299}$ it was brought to challenge the validity of the Georgia county unit system. The case was filed, it is said, within half an hour after the decision in Baker $v$. Carr was announced. It was heard by a three-judge court consisting of Judges Bell, Hooper, and Tuttle.

The treatment of the Georgia county unit cases by the Baker Court has already been discussed. The Brennan opinion refers to these cases as involving a refusal to use equity's powers. The Douglas opinion leaves them all to Brennan. The Clark opinion treats them as having demonstrated the policy of abstaining from interference where the system is rational. The Stewart opinion does not mention them at all. And the Frankfurter and Harlan opinions treat the cases as still good law. At the very outside, then, it cannot be said that Baker can stand as a precedent rejecting South $v$. Peters as applied to its precise facts.

While the Sanders case was in gremio legis, the Georgia legislature acted to ameliorate to a considerable extent the rural bias built into the county unit system. The original six-four-two formula was abandoned and Fulton County was given forty unit votes, Dekalb, twenty, Chatham, sixteen, down to two apiece for the smallest ninety-seven counties.

The court stated that it took the decision in Baker v. Carr as adopting the test stated in Mr. Justice Douglas's dissenting opinion in South v. Peters, that "where nominations are made in primary elections, there shall be no inequality in voting power by reason of race, creed, color, or other invidious discrimination." 300 This prompted test number two. "Having applied the equal pro-

\footnotetext{
295203 F. Supp. 152 (N.D. Ga. 1962) [for later history, see note 300 infra].

296329 U.S. 675 (1946).

297339 U.S. 276 (1950).

298342 U.S. 936 (1952).

299357 U.S. 916 (1958).

300 See Sanders v. Gray, 203 F. Supp. 158, 168 (N.D. Ga. 1962), vacated and remanded, 31 U.S.L. WEEK 4285 (U.S. March 18, 1963), with the Supreme Court holding that the equal protection clause required application of the "one person, one vote" principle to statewide voting, but expressly indicating that its decision did not at all relate to state legislative apportionment questions.
} 
tection clause ... we apply the test of invidious discrimination." 301 The unit system, it said, is not illegal qua unit system, but it must not run "afoul of constitutional inhibitions." Step three is the formulation of a test for "invidiousness." The right of an individual, said the court, must be related to the treatment of his county as against the state as a whole, and he cannot complain of over-influence of some other county, but only under-influence of his own. ${ }^{302}$ This was said to be so because the state has a power to "diffuse" political initiative, a power upheld in MacDougall $v$. Green. ${ }^{303}$ Another factor to be considered, said the court, is whether there is a historical basis for the unit system. It went on to find such a basis. A third consideration was said to be whether or not there is a political remedy. It found that there was not. A fourth factor is the relationship between federal and state governments under the Constitution. A federal court should not interfere unless violation of the right is clear. ${ }^{304}$ The test to be applied, concluded the court, is "the sum of all these factors." The application of that sum appeared to the court to point to two conclusions: first, "a unit system for use in a party primary is invidiously discriminatory if any unit has less than its share to the nearest whole number proportionate to population, or to the whole of the vote in a recent party gubernatorial primary or to the whole vote for electors of the party in a recent presidential election"; and second, "no discrimination is deemed to be invidious under the system if the disparity against any county is not in excess of the disparity that exists against any state in the most recent electoral college allocation, or under the equal proportions formula for representation of the several states in the Congress, . . . provided it is adjusted to accord with changes in the basis at least once each ten years." 305 The court indicated that it was aware of the fact that it might be thought doctrinaire thus to state "definite standards," and said that it did so, "because, and only because, it is a question of much public moment."

So after the Supreme Court refused four times to invalidate a unit system with top-to-bottom variation of over one hundred to one, the district court has held that thirteen to one is "afoul" the

301 Sanders v. Gray, supra note 300, at 168 .

302 Ibid. Compare with this test that espoused by the district court in Baker $v$. Carr, 206 F. Supp. 341 (M.D. Tenn. 1962), where it was said that the right violated was a right not to be treated differently from citizens in the "irrationally favored counties." Id. at 344

303335 U.S. 281 (1948).

304 Sanders v. Gray, 203 F. Supp. 158, 168-69 (N.D. Ga. 1962) [for Iater history, see note 300 supra].

305 Id. at 170 . 
Constitution. The case is presently on appeal to the Supreme Court and will offer a test of the revolutionary character of the Baker decision. Plainly the district court found no irrationality other than what it found to be an unfair differential. Like the district court in Tennessee in the Baker case on remand, it fixed the limits of fairness within very narrow tolerances. In Baker, the outer range of reasonableness was placed at a two-thirds fraction rule. The Georgia district court was willing to go along with a major fraction rule.

The second of the Georgia cases, Toombs $v$. Fortson, ${ }^{306}$ tested the apportionment of the state legislature. The Georgia constitution, like that in New York, provides for legislative apportionment of the lower house according to a formula protecting the representation of smaller counties. The difference is, however, that the Georgia house of representatives has 205 members and there are 159 counties. The formula allots to the eight largest counties three representatives apiece, to the thirty next largest, two, and one each to the remaining 121 counties. This results in a difference of ratio of roughly one hundred to one.

Not only is the Georgia case distinguishable on the ground of order of difference, but, unlike New York, Georgia had apportioned the senate without regard to population. The senate districts were in all but two cases groups of three counties, with each district electing one senator. In all but two cases the law forbade a senator to succeed himself or be succeeded by a resident of the same county. Instead, each of the three counties in a district was entitled to have one of its residents in the senate in every third session. This was accomplished by holding the primary election only in the county whose turn it was, though, in the general election, voting was throughout the district. Since senate districts were each composed of the same number of counties, the rural bias in the senate is substantially the same as it is in the house of representatives. Under the rotation system, counties due to have a senator in the state's twenty-eight least populous districts, although representing only 6.13 percent of the state's population, would elect a majority of the fifty-four member senate.

Following the same "sum" of tests employed in Sanders $v$. Gray, the court held that the rotation system of electing senators was unconstitutional, and that a representative system which does not elect at least one house by population involved "invidious discrimination" under the equal protection clause. Whether or not 
one house could be apportioned on a purely geographical basis it did not feel obligated to say. ${ }^{307}$

As in Tennessee, relief proved to be a problem. During the pendency of the Sanders case, the governor had called a special session of the legislature and it had taken action on the unit system. It had adjourned, however, without doing anything about legislative apportionment. In its original opinion, written by Judge Tuttle, and filed on May 25, 1962, the court indicated that it would postpone further proceedings "until the State has had a reasonable opportunity to reconstitute the Legislature so as to meet the constitutional standards here laid down prior to the January, 1963, session." ${ }^{308}$ In mid-July nothing had been done to correct the abuses pointed out by the court, and it rendered a second opinion to clarify the first. ${ }^{309}$ This opinion, delivered by Judge Bell, and joined in by Judge Morgan, limited the effect of the first opinion to a declaration of the invalidity of the rotation system in the senate and the unconstitutionality of a system in which neither house is apportioned by population, with an indication that if nothing is done to achieve a system in conformity with those standards by January 1963, the court would have a duty to take such action as would be necessary to afford plaintiffs their rights. The court did not decide, said Judge Bell, that the legislature would not have any legal status after January. On the contrary, "its present status will continue until changed." Tuttle dissented from this clarifying opinion. $\mathrm{He}$ indicated that what the court intended to say and, so far as he knew, still intends to say, is that "unless at least one House of the Georgia Legislature is reconstituted so as to represent the people of the State according to population by January 1, 1963, no legally constituted Legislature of the State of Georgia will then be in existence or thereafter be in existence." 311

Just what method of reapportionment could be resorted to after January 1, 1963, Judge Tuttle does not explain. Presumably he was of the opinion that, after the seven-month period of grace, the court would in some fashion act directly "to accord plaintiffs their rights." This threat was one which Judge Tuttle had delivered from the bench. On his invitation to express contrary views, his

307 Ibid.

308 Id. at 259.

309 Toombs v. Fortson, Civil No. 7883, N.D. Ga., July 13, 1962 (memorandum opinion filed with order).

310 Id. at 2.

$311 \mathrm{Id}$. at 8 . 
brothers Bell and Morgan had expressed none, and Judge Tuttle shows some pique at their later disassociation from his view of the matter. His position is strange, inasmuch as one would expect that in a case in which relief is one of the major problems, the court would not act to limit the avenues of possible action until it was forced to. The presence of a sitting legislature, for example, widens the possibilities for equitable pressures. Perhaps Judge Tuttle thought that the present threat of chaos in January would effect action and that the court's failure to back up its threat would encourage foot-dragging. ${ }^{312}$

The third volume in the Georgia trilogy is Wesberry v. Vandiver. ${ }^{313}$ This case rounded out the effort to test the application of Baker $v$. Carr ${ }^{314}$ to all the types of apportionment sustained in the thirty years of litigation preceding the Baker case. It was filed to challenge the constitutionality of the Georgia congressional apportionment, raising again the same issues which were before the Supreme Court in Wood v. Broom ${ }^{315}$ and Golegrove v. Green. ${ }^{316}$

First the court applied to congressional apportionment the test it had worked out in the unit rule and legislative apportionment cases. It pointed out that the act in question was enacted in 1931, following the loss by Georgia of two seats in the House of Representatives. Though the districts created by that act varied in population from a high of 396,112 to a low of 218,496 , the court could not say that it thought the plan at that time arbitrary. It stated that the 1931 act created districts which "reflected a rational state policy to set up the congressional districts in Georgia with some reasonable relation to population." It continued to say that "on the other hand it now reflects a system which has become arbitrary through inaction when considered in the light of the present population of the Fifth District and as measured by any conceivable reasonable standard." 317

In the congressional situation, however, the court felt that judicial intervention should await the passing of a reasonable time to allow "normal state governmental processes" to correct the

312 On September 27, 1962, the Governor of Georgia called the legislature into extraordinary session, and, on October 5, 1962, the legislature enacted legislation reapportioning the state senate. Under the scheme there adopted, urban counties are given twenty-three of the fifty-four seats in the senate, with twelve allotted to metropolitan Atlanta. See Council of State Governments, Legislative Apportionment IN THE STATES (1962 \& Supp. I, 1963).

313206 F. Supp. 276 (N.D. Ga. 1962).

314369 U.S. 186 (1962).

315287 U.S. 1 (1932).

316328 U.S. 549 (1946).

317 Wesberry v. Vandiver, 206 F. Supp. 276, 282 (N.D. Ga. 1962). 
alleged abuses. Tested by the fourteenth amendment and article I, section 2, rights of the plaintiffs, the court suggested that it would decline to find invidiousness at the present time, but would retain jurisdiction until a reasonable time had been afforded a reapportioned General Assembly to reapportion congressional seats. ${ }^{318}$

The court did not do this, however, for it read the Colegrove case as bringing into the congressional apportionment problem the role of Congress. Colegrove, as applied to congressional apportionment, the court took to be binding. It was cited as authority in cases in which there was only "state action," and perhaps, in view of Baker $v$. Carr, is no longer binding in such cases. In the area of congressional apportionment, however, the court did not take Baker $v$. Carr to repudiate its holding, particularly since it was expressly preserved in the previous term in Gomillion v. Lightfoot. ${ }^{319}$ In view of these considerations, the court felt that the complaint should be dismissed for want of equity "to the extent that no cognizable constitutional claim is presented under the facts and subsisting authorities." 320

Judge Tuttle disagreed with the majority in their view that Colegrove v. Green was preserved in Baker v. Carr. He would have denied relief on the ground that political remedies were available through a reapportioned legislature, but would have retained jurisdiction over the cause in order to grant relief if political processes should prove unavailing. ${ }^{321}$

\section{B. Sims v. Frink:}

\section{The Alabama Do-It-Yourself Apportionment Kit}

The Alabama apportionment situation was closely analogous to that in Tennessee. The state constitution provided for legislative apportionment according to population. As in Tennessee, the last Alabama reapportionment had taken place in 1901. In Sims v. Frink ${ }^{322}$ a suit was brought before a three-judge court to reap the rewards promised by Baker $v$. Carr. The court took as conceded that the apportionment in both house and senate under the 1901 act embodied invidious discrimination. The General Assembly was called into extraordinary session to forestall judicial intervention and adopted two pieces of legislation. The first

318 lbid.

310364 U.S. 339 (1960).

320 Wesberry v. Vandiver, 206 F. Supp. 276, 286 (N.D. Ga. 1962).

321 Ibid.

322208 F. Supp. 431 (M.D. Ala. 1962). 
was a temporary or "stand-by" legislative apportionment act alleviating to some extent the "glaring discrepancies." ${ }^{23}$ The second was a proposed constitutional amendment which would create a senate of sixty-seven members, one from each of the sixty-seven counties in the state. ${ }^{324}$ The house, on the other hand, would be apportioned on the basis of population. Since the proposed amendment to the constitution of Alabama further required that in distributing representatives by population every county should be given at least one representative, the court read the proposal as providing less than mathematical proportion to population. It went on to say that, although there had been some suggestions in the district court cases since Baker v. Carr that a system in which the apportionment of one house is based on population and the other is based on geography might meet muster, where the detailed provisions of the local constitution, as in Alabama, make exact apportionment by population impossible in either house, the result may well be to require at least some attention to population in both. ${ }^{325}$ In view of the detailed requirements of the proposed constitutional amendment, making exact proportion impossible in the house, it ruled that the proposal for a one county-one senator senate would be unconstitutional. The proposal for distribution of the seats in the house it felt was within constitutional limits, however.

The stand-by statute was declared unconstitutional in that its provisions for the distribution of house seats embodied invidious discrimination, and, further, that it was to take effect only after November, when the people were to vote on the proposed constitutional amendment. The court seemed to feel that since it had declared that the acts proposing the amendments were unconstitutional, an act to take effect after the date set for their submission would be unconstitutional as a needless delay in affording the plaintiffs their constitutional rights. ${ }^{326}$

Having declared the stand-by act and the act proposing the constitutional amendment unconstitutional, the court was left with no governing provisions at all. It thereupon simply issued an order adopting its own apportionment plan to be effective

323 Alabama House Bill 59, Extraordinary Session, 1962, known as "Crawford-Webb Act." The text of the act is reproduced as appendix $C$ to the court's opinion; see Sims v. Frink, supra note 322 , at 445 .

324 Alabama Senate Bill 29, Extraordinary Session, 1962, known as "67 Senator Amendment." The text of the proposed amendment is set out as appendix B to the court's opinion; see Sims v. Frink, supra note 322, at 443.

325 Sims v. Frink, 208 F. Supp. at 439.

328 Id. at 441. 
immediately, but subject to the power of the present legislature to supersede it with legislation enacted before the next elections. ${ }^{327}$ The court took the stand-by act provision for senate apportionment and the plan embodied in the proposed constitutional amendment for apportionment of the house of representatives, and incorporated them in its order. Thus a federal court has declared half of a state constitutional amendment unconstitutional before it was adopted, and adopted the other half for the people of the state before it was voted on.

The court did not take the system it adopted to be a full measure of absence of invidiousness. It quoted from Mr. Justice Clark's Baker opinion to the effect that perhaps the courts could correct some of the egregious discrepancies and thereby break the stranglehold. Jurisdiction was retained for the purpose of examining the action of the next legislature in adopting a permanent system consistent with constitutional principles. To add insult to injury, costs were taxed to the defendants. ${ }^{328}$

\section{Moss v. Burkhart}

Moss v. Burkhart ${ }^{329}$ was an action brought to force the Oklahoma legislature to apportion in consonance with Baker v. Carr. The case was, as was stated by the district court, a sequel to Radford $v$. Gary. ${ }^{330}$ The alleged discrepancy between ratios of representatives to those represented was approximately ten to one. It will be remembered that in Radford the relief sought had been mandamus to the governor to call the legislature, to the legislature to reapportion, and, failing that, to the Supreme Court of Oklahoma to do it for them. Mr. Justice Brennan had distinguished the case from that in Baker as controlled by "problems of relief." In Moss $v$. Burkhart the plaintiffs requested that the court "proceed to enjoin the State Auditor, State Treasurer, and Members of the Oklahoma Tax Commission from taking any official actions on appropriations or enactments of those claiming to exercise legislative authority." 331 They added, however, that if they be mistaken in the remedy sought, they be granted such remedy as would relieve and cure the evils from which they continued to suffer.

The Governor of Oklahoma appeared voluntarily and testi-

327 Id. at 442.

328 Perhaps under a theory of quantum meruit.

320207 F. Supp. 885 (W.D. Okla. 1962).

330 Id. at 887 .

331 Ibid. 
fied to the effect that he was elected governor on a program to reapportion the legislature, had recommended reapportionment according to the constitutional mandate, and had sponsored an initiative petition to effect reapportionment, but that it had been defeated at the polls, and further that he had appeared as a defendant and as an amicus curiae in cases before the Oklahoma Supreme Court, had suggested modes of relief to that court, and had offered to convene the legislature in special session if the court would indicate its disposition to afford relief in the event the legislature failed to act. This offer he repeated to the federal district court in Moss. The court refused interlocutory relief to give the legislature an opportunity to act. After hearing, the court declared the Oklahoma constitutional provision limiting the number of legislators from one county to seven to be null and void, and that the present apportionment statute was also null and void, but made this ruling prospectively, with effect upon "all future elections." 332

This ruling was handed down June 19, 1962, and the case was continued to July 31,1962 , presumably to give the legislature an opportunity to act. When the court reconvened the legislature had not acted. There was before it a motion to alter or amend the decree and for a consideration of various remedies. The motion was overruled, except that, by way of clarification of the earlier order, the court said that it had not meant to indicate that a general assembly elected in the November 6, 1962, election would not be legally constituted. Since the filing period for the 1962 election had already begun when the interlocutory decree was rendered, it would not be considered a "future election." 333

It then proceeded to set down "guidelines" for the 1963 session of the legislature. First, the state was to be apportioned on a basis of substantial numerical equality, to the end that each voter shall have approximately the same power and influence in the election of members of the two houses. This, said Judge Murrah, is in consonance with the intent and spirit of the Oklahoma constitution and the equal protection clause. He did not say whether he read them separately or together. Second, the house of representatives shall be apportioned according to the requirements of the Oklahoma constitution, except that the seven-member limit shall not be followed, it being found and declared unconstitutional under the fourteenth amendment; the 
said seven-seat limit being removed, Oklahoma and Tulsa counties are to have nineteen and fourteen legislative seats, respectively. Third, the senate shall be apportioned according to the provisions of the Oklahoma constitution, except that, there being two irreconcilable provisions therein, the court will prefer the one which provides for exact equality. It then proceeded to allot the proper portion to the single-county districts and state that the rest shall be coupled in the way which will give them as nearly as possible equal population, and compactness and contiguity. ${ }^{344}$

On the surface, Judge Murrah's opinion seems to indicate that it is the court's duty not only to force apportionment consistent with the fourteenth amendment, but to require a full observance of the provisions of the Oklahoma constitution as well. The fact that he found the seven-member limit unconstitutional, however, may indicate that he believed the Baker case to require absolute numerical equality. This does not necessarily follow, for he may be of the opinion that the seven-member limit fails to meet the test of the equal protection clause, and, with the offending clause being struck from the Oklahoma constitution, that instrument requires absolute uniformity in both houses. In view of the insistence of the majority of the Baker Court that it was not being called upon to enforce provisions of the state constitution, Judge Murrah's position is a strange one. It does have the advantage of providing a standard, however. If he is holding that absolute equality is required in both houses, certainly his opinion is not even consistent with the views expressed by Mr. Justice Douglas in his concurring opinion in Baker v. Carr.

Like the district court in Tennessee, Judge Murrah and his brethren are left at "ducks and drakes" until the Summer of 1963. He suggested that if there is no acceptable legislative apportionment statute forthcoming, he will proceed to direct methods.

\section{Sobel v. Adams}

The Florida apportionment was further from being proportional to population than most, a member of the lower house from Gilchrist County representing 2,868 voters, and one from Dade County, 311,000, a difference of over one hundred to one. The suit was brought in the United States district court and heard by a three-judge panel. The court had little trouble in coming to the conclusion that the apportionment of the house of representatives was in violation of the Constitution of the United States.

334 Id. at $898-99$. 
It also indicated that it considered that proposed constitutional amendments would be unconstitutional, but declined to enjoin their submission. Finally, it declared the house apportionment act "null, void, and prospectively inoperative," and continued the case until August 13, 1962. ${ }^{335}$ The following day the governor called the legislature into extraordinary session, and it withdrew the proposed amendments and substituted one which provided a scheme for the house of representatives under which each county would have one representative and the remainder would be apportioned according to population. The senate would be composed of forty-six districts, each district to elect one senator. Each of the twenty-four most populous counties would constitute a district, and the other twenty-two districts would be composed from the remaining forty-three counties. ${ }^{336}$ To implement the provisions of the proposed constitutional amendment, the legislature enacted two statutes, one making an apportionment of the house of representatives in accordance with the formula set out in the proposed amendment, ${ }^{337}$ and the other making provision for senatorial districts of the number specified by the same amendment. $^{338}$

The court, per Judge Jones, held that, if the amendment is adopted in November 1962, the state will have provided for a rational system of apportionment. ${ }^{339}$ Judge Jones rejected the suggestion that the equal protection clause required precise numerical equality in districts in either house of the legislature. In the house of representatives he felt it perfectly rational to preserve minimum geographical representation by requiring that each county have at least one representative. The senate districts, he suggested, might seem at first to be a crazy quilt but on closer examination to follow overall rational lines. He laid emphasis upon the fact that the Florida legislature enacts a great deal of local legislation and for that reason it was sensible to have no more than three counties to a single senator. The case was continued with the statement that, if the amendment is ratified, the cause will be moot and will be dismissed.

335 Sobel v. Adams, 208 F. Supp. 316, 318 (S.D. Fla. 1962).

336 Fla. Legis., H.R.J. Res. 30-X, Ex. Sess. (1962), found in FlA. Stat. ANN. art. 7, \$§ 1-6 (1962); see Sobel v. Adams, supra note 335, at 319 .

337 See Sobel v. Adams, supra note 335, at 319 .

338 Id. at 320.

339 On November 6, 1962, this proposed amendment was rejected at the polls. Thereupon the governor issued a call for a special session of the legislature. The session convened on November 9 and sat until November 27. No apportionment legislation was adopted, but a special study committee was formed to make recommendations to the new general assembly when it convenes in regular session on April 8, 1963. 


\section{E. Lisco v. McNichols}

This case involved a suit to enjoin enforcement of the Colorado legislative apportionment statutes. ${ }^{340}$ It was brought against the governor of the state, the state treasurer, and the General Assembly. They answered, challenged the jurisdiction of the court, and asserted their immunity from suit. The court found that it did have jurisdiction and that the suit was not against the state. It found, further, that the present Colorado apportionment did not meet with the requirements of the equal protection clause, that is to say that it is characterized by invidious discrimination against those living in districts with a large population. The court noted, however, that the primary election was scheduled for September 11-it then being August 10 -and that the case had been tried in less than two days, affording no opportunity to explore various modes of relief. Under the circumstances, the court felt that it should grant no injunction but should stay action until an indefinite date in the future, giving the 1963 legislature an opportunity to act.

\section{vil. The State Court Cases}

The role of the state courts in the efforts to keep apportionment plans current has often been commented upon. Suffice it to say that none of the Supreme Court cases announcing the nonjusticiability rule or holding against the existence of federal rights in any way limited or defined the state courts' powers to grant relief to correct abuses under the state constitutions. It has already been pointed out that in Illinois the state supreme court enjoined the expenditure of state funds in the holding of an election under an invalid apportionment statute. ${ }^{341}$ Other state courts have fashioned other modes of relief. ${ }^{342}$ Many of the state courts, however, have followed the course of the Supreme Court in its refusal to intervene. ${ }^{343}$ This refusal generally has been grounded on the absence of power to grant relief, since in many instances the violation of the state constitution has been too plain for argumentation. The question raised by the Baker case with respect to these decisions is whether the announcement that an invidious discrimination based upon residence of the voter constitutes a violation of the federal constitution has the effect of conferring

340 Lisco v. McNichols, 208 F. Supp. 471 (D. Colo. 1962).

341 See Moran v. Bowley, 374 Ill. 148, 179 N.E. 526 (1932).

342 See, e.g., Asbury Park Press, Inc. v. Woolley, 33 N.J. I, 161 A.2d 705 (1960).

343 See generally Sears, MEthods of ReApportiondent (1952). 
jurisdiction on state courts to deal with their legislatures in a way in which they had previously decided was ultra vires. If the effect of the Baker decision is to confer such jurisdiction, a second problem remains. If the state court may now act to require conformance to the minimal standards of the equal protection clause, may it take as its gauge of fairness the provisions of the state constitution where those provisions are more strict than those required by the equal protection clause?

The problem is touched upon in Stein $v$. General Assembly, ${ }^{344}$ a case brought in the state courts in Colorado after the Supreme Court decision in Baker v. Carr. In the Stein case a suit was brought in the Supreme Court of Colorado seeking a prerogative or remedial writ: first, ordering the General Assembly to convene for the purpose of reapportioning the seats in the legislature; second, requiring the governor to convene the legislature for such purpose; third, prohibiting the secretary of state from "permitting the conduct of elections or certifying to office any person as elected to the General Assembly until there be such reapportionment ..."; and fourth, prohibiting the state treasurer from paying to any member of the General Assembly any of the emoluments of his office until there be reapportionment as provided by the constitution of Colorado. The gravamen of the Stein case is the failure of the Colorado legislature to reapportion the state under the requirements of the constitution of Colorado. The constitutional provision required apportionment based upon population, and its validity was not at issue. The Colorado legislature was last apportioned in 1953. The constitution provided that apportionment should take place in 1885, "and every tenth year thereafter; and at the session next following such enumeration, and also at the session following an enumeration made by the authority of the United States. ..."345 The complaint stated that the governor had certified the census figures to the legislature in 1961, and in 1962, and at both sessions the legislature had failed to act. Between 1950 and 1960, Colorado had increased its population by 32.4 percent, urban population increasing by 55.5 percent, while rural population showed a decline of 6.6 percent. As a result, it was urged, there existed in 1962 an unconstitutional irrational preference for urban voters. Justice Day, speaking for three members of the seven-man court, began by saying that it should be made clear that the Supreme Court of Colorado could not and would not 
order the governor to do anything, "the doing of which lies within his sound discretion," and further that the court was of the opinion that the calling of special sessions of the legislature was such a prerogative. It went on to say in like fashion that the court could not grant the relief sought against either the state treasurer or the secretary of state. Justice Day thought, however, that the fact that the plaintiff might have misconceived his remedy would not divest the court of jurisdiction. ${ }^{346}$ On the merits, the court held that the state constitution required apportionment during the odd-numbered year following the census so that on the facts the legislature was not as yet derelict in its duty. It stated, however, that the apportionment was discriminatory and retained jurisdiction.

There were two dissents, each of interest, but for different reasons. On the subject of state court remedies, Justice Hall, noting the requested relief, was of the opinion that the court, having come to the conclusion that none of the majority was ready to afford any of the remedies sought, should dismiss the suit. ${ }^{347}$ He considered all of them to be beyond the powers delegated to the judiciary. Since he felt that the majority had in effect held that the time for legislative action had not arrived, it was unbecoming of the court to retain jurisdiction, and those persons charged with constitutional and statutory duties "are entitled to go about [their] performance ... untrammelled by threats or warnings from this court, no matter how hollow or impotent they may be." Justice Moore, on the other hand, saw a violation of the Constitution of the United States under the Baker doctrine, and believed that whenever such a violation is shown to exist, it is not within the power of the state to postpone correction because of any variety of "state action." 348 This view of the matter appears to suggest that decennial apportionment requirements themselves cannot be justified as reasonable where great shifts take place in a shorter time, a view which is in sharp contrast to the view of the federal district court in New York which suggested that the provision of the law of that state calling for a vote every twenty years on whether a constitutional convention shall be held established a political corrective to be weighed in determining whether or not a court should intervene.

On the subject of jurisdiction, the Colorado court had no doubts, but it may be doubted that this was the result of Baker $v$.

348 Id. at 73 . 
Garr, for as early as 1934 it had taken jurisdiction to test the validity of apportionment legislation, holding the act of that year unconstitutional.

These same doubts about power to afford equitable relief are to be seen in Sweeney $v$. Notte, ${ }^{349}$ in Rhode Island. There a suit was brought to challenge the validity of a legislative apportionment of the Rhode Island house of representatives under a constitutional provision requiring that at least one representative be given to each of the municipalities in the state. The legislature of Rhode Island, like that of Colorado, had failed to reapportion on the basis of the 1960 census. The court found that discrepancies in representation ratio were as great as four to one. It also found, however, that there was no way to achieve equal apportionment in the house of representatives consistent with the provisions of the constitution requiring representation of the municipalities and limiting the number of seats to one hundred. ${ }^{350}$ It was troubled by the possibility that it might declare that the General Assembly had a duty to apportion under the existing provisions, only to find out later that these requirements violate the United States Constitution. It took the bit in its teeth and held that strict adherence to both the municipality representation and the one hundredmember limit would make a constitutionally valid apportionment impossible, but declined to direct the General Assembly as to which it should follow. As to relief, the court said:

"In the absence of constitutional warrant to the contrary this court has no authority to require the general assembly to meet in special session, nor to require the governor to exercise his constitutional prerogative to call such a session. Furthermore, we are not persuaded that our obligation to resolve the justiciable issues herein considered is so broad as to require us to hold that the superior court would be warranted in supervising reapportionment of the house of representatives. ..."351

It stated further that it felt obligated to say that if the legislature

349183 A.2d 296 (R.I. 1962).

350 This view was repeated in Opinion to the Governor, 183 A.2d 806 (R.I. 1962). The constitutional provision in question required $1 \%$ representation of the state's thirty-nine municipalities. The court gave its opinion that there was no way of conforming to this provision and to the 100 -member limit while satisfying the requirements of the equal protecton clause. The best that could be done under the provision would result in a minimum difference in ratio of between four to one and twenty-two to one, "which in our opinion would be so unjustly discriminatory as to be invidious." Id. at 807.

351183 A.2d 296, 303 (1962). 
did not reapportion the state, some federal court would probably do it for them.

Justice Roberts concurred in an opinion in which he said that he thought the court had gone pretty far in considering the provisions of the state constitution. He thought the proper function of the court was to declare the legislature's duty to reapportion under the constitutional mandate and leave the validity of that provision for later litigation. ${ }^{362}$

\section{ConCLUSIONS}

Although the reactions have varied from huzzahs to Minié balls, this generation has learned to live with a Supreme Court which has defined its function as including reform as well as enforcement of the community's standard of minimum fair treatment. At the very least it can be expected that the concept of fairness will change over the years, and we are accustomed to having such changes reflected in a shifting construction of the constitutional phrases "due process" and "equal protection." There is nothing very revolutionary, then, in finding that the Court will inquire into allegations of arbitrary discrimination based upon a person's place of residence. Nor is there much that is surprising in a holding that this will be so in cases dealing with matters of franchise; the fifteenth amendment cases have schooled us to think it normal for courts to interfere in such matters.

The United States, like other nations around the world, has found no answer to the question, "How 'ya gonna keep 'em down on the farm?," and mid-twentieth century finds us primarily an urban nation. It is not surprising, then, that the Court should investigate such discrimination at the instance of urban dwellers, constituting, as they do, some sixty-nine percent of the population, well-organized, and loud. Matters of constitutional right are ruled no doubt partly by pity, but partly by noise.

The most disturbing feature of the apportionment cases is the fact that beneath the surface of every one of these cases, and not very far beneath at that, lies a partisan political struggle. There is no doubt that from first to last these cases have been brought to challenge the validity of a system which accords concentrated urban populations less representation than they would receive were representatives allotted on the basis of population alone.

352 Id. at 304. Justice Roberts stated: "The courts of this state, in my opinion, are without power, inherent or conferred, to apportion the house of representatives either directly or indirectly by resort to the equity jurisdiction." Ibid. 
The problem has never been one of whimsical or irrational allocation, or discrimination against individuals because they live at a particular intersection between meridian and parallel. The residents of Memphis care not at all whether Moore County, Tennessee, is given a single representative or coupled in a floterial district with Coffee County, unless perhaps they think that one solution or another will make it more probable that the district will return a member of the Memphis political stamp. The contest is not between people living in one area or another; it is between Democrats and Republicans.

Courts are themselves frequently in need of protection from partisan politics, and for this reason traditionally they have kept out of partisan struggles. They have said to the politician, "I'll stay out of your arena, and you keep your gladiators out of my court room." This has not always been so, and in some states we still retain political elections of judges, but in the federal judicial system this detachment from politics has been thought of as an aid in maintaining an honest, impartial, and independent judicial establishment. A political judicial branch will be politically curbed, and should be. As long as we view courts as arbiters of disputes between individuals, and protectors of individuals against oppression by the state, it is sensible to want judges of fair mind and independence. When courts undertake to manipulate and control the processes for selection of the politician, what is more natural than for the politician to marshal his resources for controlling the selection of the judge? It is true, of course, that political connections are not at the present time an inconsiderable feature of judicial appointment; it is not, however, a feature which most thinking people wish to see grow.

A second disturbing feature of judicial embroilment in matters of this sort is the absence of any ready yardstick for measuring the right asserted. It is all very well to stand ready to protect citizens from clear abuses of rights or, as Mr. Justice Clark says, from the operation of systems without any logical justification. Since in representation geography is obviously a secondary device, under which there is an untold number of political alignments and crossalignments fitted together by bargain, it is in a rare case, indeed, that, by standing aside and looking at the system, one can tell whether it is a "crazy quilt" or an authentic "action painting."

The experience thus far with the district court decisions applying the Baker case illustrates the problem. There have been almost as many views of what equal treatment is as there have 
been courts which have considered the matter, and frequently the members of a single court have had widely diverging views. As one would suspect, they cluster around three positions. The first, consonant with the views already expressed here, is that mere difference is not enough, and that, where the court can think of possible benign motives for the differences, it should not interfere. A second position is that substantially equal representation of geographical units according to population is required in one house of the legislature, but geographical representation without regard to population may be employed in the other. The third position is that representation in both houses must be governed by standards of equal representation, insofar as it is possible to achieve equality among the geographical areas forming the units for representation. Because of the disruption these cases have threatened, many states have proceeded to try to meet the requirements laid down, without waiting for final determination by the Supreme Court of the standards to be employed. In some quarters this may appear to be a victory for intervention, since it avoids the problems of affording any positive relief. It may be, however, that in some cases systems of representation perfectly consonant with the equal protection clause, as the subject right will evolve through subsequent decisions by the Supreme Court, will have been given up and, because of the shifts in power resulting from the changes forced under threat by the courts, will be irretrievable. The new system may, of course, be better-or worse. In either case, it is difficult to agree with the propriety of effecting such changes through judicial duress.

The third criticism which may be warranted goes to judicial method. Though the bar and the public are conditioned to change in the definition of constitutional rights, the judgment of courts is entitled to respect largely because we view it as the product of wisdom and reason. The Court is the agency which interprets our history and tradition in light of present circumstances. Though presumptions run against it, cases may arise in which a long series of decisions, proceeding from an original faulty premise, have for many years perpetuated a condition which the Court thinks antithetical to our true tradition. If the Court were ready to say that the apportionment cases are of this sort, it could have said so. Instead, it tortured the precedents beyond recognition and, without giving any guiding principles, invited the district courts to entertain the welter of suits it must have anticipated-and on the eve of primary elections in many states. In a nation with fast- 
growing urban populations, the substance and effect of the Court's action will probably be popular, though ultimately it may complicate its existence and in the long run endanger its independence. Its method, however, was more crafty than craftsmanlike, and cannot add to the prestige that comes from a reputation for honest reading of the past coupled with sound and considered judgment in applying past to present.

The manner of disposing of Baker, Scholle, and Simon, and the spate of cases which Baker has brought, makes it certain that the Court will have early and ample opportunity to attack the task of framing guiding principles. It is to be hoped that it will not be ducked by a dozen years of per curiam decisions citing Baker v. Carr and, further, that the advantages of simplicity will not prompt adoption of a standard of mathematical equality based solely upon population, thus ending centuries of experimentation with the design of democratic institutions which will accommodate within the same unit of government a wide variety of interest groups without subjecting all to absolute domination by a close majority which is geographically concentrated and highly organized. 